\title{
Meeting the Challenge: Rethinking Judicial Disqualification
}

Recent congressional proposals to allow litigants in federal courts to clrallenge pereinptorily the trial judge assigned to their case have caused old and bitter debates to resurface. ${ }^{1}$ Supporters of sucl a measure contend that it will enhance public confidence in the judiciary and that the system has worked in several states. ${ }^{2}$ Opponents claim the challenge will lead to judge-shopping and dilatory tactics by counsel. ${ }^{3}$

The lively debate is evidence that, despite recent federal reforms ${ }^{4}$ and the wide adoption of the American Bar Association (ABA) Code of Judicial Conduct, the law of disqualification remaims unsettled. Much of the confusion stems from the lack of a clear theoretical base for disqualification law-disqualification is granted for distimct substantive reasons, by different procedural methods. Frequently, disqualification is based on such often used but rarely analyzed concepts as "public confidence" and "the appearance of justice." This Comment seeks to untangle the law of disqualification through examination of the federal and Califorma standards. ${ }^{5}$ It will argue that the federal system would

1. See, e.g., Slonim, Bench-Bar Clash Looms Over Challenges to Judges, 66 A.B.A. J. 1503 (1980) (quoting U.S. District Judge Robert Chapman as describing the suggestion "the worst [proposed] legislation that has ever been introduced"); The National Law Journal, Aug. 11, 1980, at 3, col. 1. Three proposals have been imtroduced recently. See H.R. 1649, 97th Cong., 1st Sess. (1981); H.R. 7473, 96th Cong., 2d Sess. (1980); H.R. 7165, 96th Cong., 2d Sess. (1980). Federal proposals to create a peremptory challenge are by no means novel. Senator Bayh introduced a similar measure in 1971. S. 1886, 92d Cong., 1st Sess., § 3 (1971). For some of the debate on this proposal, see Judicial Disqualification: Hearings on S. 1064 Before the Subcomm. on Improvements in Judicial Machinery of the Senate Comm. on the Judiciary, 92d Cong., 1st Sess. \& 93d Cong., 1st Sess. 1-71 (1971-1973) [hereinafter cited as Senate Hearings on S. 1064]; Frank, Disqualification of Judges: In Support of the Bayh Bill, 35 LAw \& CONTEMP. PROB. 43, 65-68 (1970) [hereinafter cited as Frank, In Support of the Bayh Bill].

2. See, e.g., Alaska Stat. $\$ 22.20 .022$ (1976); ARIz. Rev. Stat. ANN. $\$ \$ 12-409$ to -411 (1956); CAL. CIv. Proc. Code $\$ 170.6$ (West Supp. 1981); Ill. ANN. STAt. ch. 38, § 114-5 (SmithHurd Supp. 1980); N.D. CENT. CODE § 29-15-21 (Supp. 1979); OR. Rev. STat. $\$ \$ 14.250$ to 270 (1979); WASH. REv. CODE ANN. $\$ \$ 4.12 .040$ to .050 (1962).

3. Slonim, supra note 1 , at 1503 .

4. In 1974, the federal statutory scheme was rewritten to reflect the ABA Code of Judicial Conduct. See 28 U.S.C. $§ 455$ (1976); 119 CoNG. REC. 33029 (1973) (remarks of Sen. Burdick).

5. The statutory schemes of the two jurisdictions deserve some preliminary explanation. Federal disqualification may arise from either $\S 144$ or $\S 455$ of Title 28.28 U.S.C. $\$ \S 144,455$ (1976 \& Supp. III 1979). Section 455 applies to all federal judges and lists the instances when a judge can be challenged successfully for cause. The statute has no procedural component. Section 144, applicable to district judges only, has both a substantive and procedural component. Procedurally, it requires an affidavit to be filed to challenge a judge. Substantively, it is aimed only at personal bias the judge harbors toward a party. The same substantive requirement is included in the present § 455. 28 U.S.C. \& 455(b)(1) (1976). Furthermore, since § 455(a) requires the judge to 
not benefit from the adoption of the peremptory challenge. Rather, what is needed is a clear rethinking of the interplay between the standards and procedures for disqualification.

Before examining the merits of the peremptory challenge, this Comment will examine, in Part $\mathrm{I}$, the existing law on disqualification. Both the substantive reasons for disqualifying a judge and the procedural methods will be exammed. Part I will show that existing law suffers from both substantive inconsistencies and questionable procedures. Part II will examine the proposed federal adoption of a peremptory challenge system, with special consideration given to the appearance of justice. Finally, Part III analyzes the goals of disqualification law and proposes a system using different procedural methods to deal with different substantive allegations of an unfair judge.

I

\section{EXISTING LAW ON Disqualification OF JUdGES}

\section{A. Substantive Standards for Disqualification}

At cominon law, a judge was disqualified only when she ${ }^{6}$ had a direct pecuniary interest in the case. ${ }^{7}$ Today, cases indicate four situations where disqualification is expected: when a judge (1) has personal knowledge of the case before her; (2) has a prior relationship linking ler with some element of the case; (3) has a financial interest in the outcome; or (4) has a personal bias or prejudice toward or agamst some element of the case.

\section{Personal Knowledge}

A judge may have acquired personal knowledge of the facts which culminated in the lawsuit before her in two ways. She may have actually been a party or witness to the acts in question, or she may have had prior judicial imvolvement with the case that educated her as to the

withdraw "in any proceeding in which his impartiality might reasonably be questioned," it is a broad standard that subsumes \& I44. See United States v. Ritter, 540 F.2d 459, 462 (10th Cir.), cert. denied, 429 U.S. 951 (1976). Thus, $\$ 144$ appears to be substantively dead but procedurally alive in conneetion with $\$ 455$ disqualifications. See note 126 and accompanying text infra.

California's scheme consists of a challenge for cause statute, CAL. Civ. Proc. CoDE $\$ 170$, as well as a peremptory challenge statute, CAL. CIv. PROC. CoDE $\$ 170.6$. While the latter obviates nuch of the necessity for $\S 170$, it does not foreclose its use. CAL. Civ. Proc. Code $\$ 170.6(7)$ (West Supp. 1981). Section 170 retains vitality when litigants have used their statutory limit of one peremptory challenge per case under $\$ 170.6(3)$. Additionally, $\$ 170.6$ applies on its face to trial courts only, whereas $\$ 170$ apphes to any justice or judge in any proceeding.

6. For purposes of clarity, this Comment will generally refer to judges as female and parties or attorneys as male.

7. Frank, Disqualification of Judges, 56 YALE L.J. 605, 609 (1947) [heremafter cited as Frank, Disqualification of Judges]. For an overview of common law development, see id. at 609 . 12. 
merits. $^{8}$

\section{a. Judge as a Party or Witness}

Certainly Lord Coke's standard that "no man shall be a judge in his own case" knows no greater violation than where the judge is a party to the underlying action. ${ }^{10}$ When a judge is intimately imvolved in a case, she may enter the matter with a predetermined view of its proper resolution. Hence, both the federal ${ }^{11}$ and California ${ }^{12}$ statutes make this an unquestionable case for disqualification for both appellate and trial judges. ${ }^{13}$ Intimate involvement likewise warrants disqualification when the judge is a witness rather than a party. ${ }^{14}$

\section{b. Prior Judicial Involvement}

A judge may gain imside knowledge about a case through prior judicial mvolvement in two ways. She may be faced with a relnand of a case over which she previously presided, or she may have been promoted to a higher court and be faced with an appeal of a case she heard below.

Since prejudice sufficient to merit disqualification must be of extra-judicial origin, ${ }^{15}$ the general rule on remands is that disqualification

8. Arguably, the worst situation in the personal knowledge category is a judge presiding over summary contempt proceedings. The judge is a witness, perhaps even a "party" to the offense in the sense that she is the victim, precisely because of prior judicial involveinent. However, federal standards bar apptication of $\S 455$ to summary contempt proceedings. See H.R. REP. No. 93-1453, 93d Cong., 2d Sess. 6, reprinted in [1974] U.S. CODE CoNG. \& AD. NEws 6351, 6355. But cf. Mayberry v. Pennsylvania, 400 U.S. 455 (1971) (when judge delays passing on conteinptuous actions until the end of the trial, another judge should be called upon to decide the question).

9. Frank, Disqualification of Judges, supra note 7, at 610.

10. Participation of a party/judge would also raise fundamental due process issues relating to a fair tribunal. See In re Murchison, 349 U.S. 133, 136 (1955). This Comment focuses on the statutory grounds for disqualification, and therefore the constitutional issues raised by due process notions are beyond its scope. However, due process requirenents provide much of the impetus for disqualification statutes. See notes 218-22 and accompanying text infra.

11. 28 U.S.C. $\$ 455(b)(5)(i)(1976)$.

12. Cal. Civ. Proc. Code $\S 170(1)$ (West Supp. 1981).

13. The absence of recently reported cases in this area suggests complete agreement with the principle. A startling comparison is Clyma v. Kennedy, 64 Coun. 310, 29 A. 539 (1894), in which the plaintiff was brought before Justice of the Peace Joln $\mathrm{H}$. Tuttle for allegedly libeling the justice. A grand juror had filed the complaint, but Tuttle not only issued the warrant for Kennedy's arrest, he also adjudged him guilty and ordered him imprisoned. The Connecticut Supreme Court ruled that Justice Tuttle was not disqualified from hearing the case because he had no pecuniary interest in the inatter. $I d$. at $318,29 \mathrm{~A}$. at 539. An opposite result on the issue of disqualification would be reached today. See ConN. Gen. Stat. ANN. \$51-39 (West 1960).

14. A federal judge is disqualified whenever she has "personal knowledge of disputed evideutiary facts concerning the proceeding." 28 U.S.C. $\$ 455$ (b)(1) (1976).

15. United States v. Grinnell Corp., 384 U.S. 563, 583 (1966); Scott v. Family Ministries, 65 Cal. App. 3d 492, 510, 135 Cal. Rptr. 430, 441 (2d Dist. 1976). 
is not mandated solely by having presided over the previous trial. ${ }^{16}$ This is justified because the remand may focus on only one element of the case, and requiring a new judge to become familiar with the entire case is a waste of judicial resources and an overreaction against a prior judge who may have erred in only a small portion of the case.

The practice of preventing a newly promoted judge froin hearing appeals im cases that she heard below is statutorily mandated. ${ }^{17}$ It appears to be based on the premise that an appellate judge is highly unlikely to reverse herself. ${ }^{18}$ While this is probably true, a trial judge may have followed the weight of legal authority even while declaring her wishes that the law were otherwise. ${ }^{19}$ In these situations, she would be quite willing to reverse herself on appeal.

Furtherinore, preventing the newly appointed judge from reviewing her own decision on appeal may only serve to delay the making of

16. See, e.g., People v. Aubrey, 11 Cal. App. 3d 193, 89 Cal. Rptr. 596 (2d Dist. 1970) (fact that judge presided over defendant's first trial does not furnish grounds for disqualification of same judge at retrial following reversal). See also Annot., 60 A.L.R.3d 176 (1974). But see Baker v. Civil Service Comm'n, 52 Cal. App. 3d 590, 125 Cal. Rptr. 162 (2d Dist. 1975) (treating § 170 motion as timely filed to disqualify judge on remand that instructcd judge to reconsider his earlier conclusions in light of a recently decided appellate case).

However, in extreme cases, as where the judge stated that a party had falsely testified at trial, remand to the same judge may be challenged. See Keating v. Superior Court, 45 Cal. 2d 440, 289 P.2d 209 (1955). Judge Finley not only refused to receive defendant's books of accounts into evidence in a fraudulent conversion action, he stated, "I have no confidence at all in Mr. Keating's integrity and veracity, and I wouldn't have any confidence in the figures . . . in those books." Id. at 442,289 P.2d at 210 .

17. 28 U.S.C. $\& 47$ (1976); CAL. Civ. Proc. CODE \& 170a (West 1954). The federal standard applies only to circuit court judges and thus apparently does not prevent a Supreme Court Justice from hearing an appeal of a case she decided while on a circuit pancl. For a list of instances of Supreme Court Justices reviewing their own decisions below, see Justice Rchnquist's mennorandum opinion in Laird v. Tatum, 409 U.S. 824, 835-36 (1972). However, the practice might still be attacked under $\S 455(\mathfrak{a})$ as one in which the Justice's inipartiality might reasonably be questioned. See Rice v. McKenzie, 581 F.2d 1114 (4th Cir. 1978) (holding § 455(a) prevcnted a fcderal district judge from hearing a habeus corpus claim arising from a case he liad decided while on the Supreme Court of West Virginia).

By contrast, the California statute applies to any judge on an appellate tribunal. The difference may refiect the fact that gaps in the California court created by disqualification are filled by assignment. See Cal. Const., art. VI, $\$ 2 \& 6$ (West Supp. 1981). On the other hand, since a disqualified Supreme Court Justice cannot be replaced, policies favoring disqualification may threaten maintenance of a quorum. 28 U.S.C. $\& 1$ (1976).

18. While a judge may feel personal allegiance to an opinion shc wrote, if appellate judges never reversed themselves, there wonld be no reason to have provisions for rehearings in the same case.

Because the federal statute does not apply to circuit court rehearings en banc, Edwards v. United States, 334 F.2d 360 (5th Cir.) (en banc), cert. denicd, 379 U.S. 1000 (1964), the pancl that decides the appeal can also sit on the rehearing en banc. This is an unjustifiable departure from the policy of the statute, since the panel of three judges who have expresscd themsclvcs on the merits of a case may affect the outcome of the rehearing in the same way that a newly appointed circuit judge may affect the panel review of a case she heard below.

19. See, e.g., Rodriguez v. Bethlehem Stcel Corp., 12 Cal. 3d 382, 387, 525 P.2d 669, 671-72, 115 Cal Rptr. 765, 767-68 (1974). 
reliable precedent until the next time a case comes up on similar facts, which is what happened in Amaya v. Home Ice, Fuel \& Supply Co. ${ }^{20}$ and Dillon v. Legg. ${ }^{21}$ The issue im both cases was whether a 1nother could recover in tort for witnessing the personal imjury of her child even if she was not $\mathrm{m}$ the zone of danger lierself. The California Supreme Court in Amaya decided slie could not, but reversed itself only five years later, and allowed recovery in Dillon. The major difference between the two cases was that Justice Tobriner liad to disqualify himself from deciding Amaya because before his appointment to the state supreme court, he had sat on the lower court tliat allowed the action. ${ }^{22}$ When Dillon came up, Tobriner did not have to disqualify himself. He ended up writimg the majority opimion that reversed Amaya and allowed the action. ${ }^{23}$

This suggests that the policies behind not allowing a judge to lear an appeal in lier own case are not sound, for a judge may be willing to reverse herself. In addition, preventing the proinoted judge from participating may only lead to a precedent that begs to be reversed.

\section{Prior Relationship}

This category involves situations where the judge lias some prior connection with one of the persons involved in the trial, as opposed to personal knowledge of the facts of the controversy. Sucli prior relationships may be eitlier family ties or professional ties.

20. 59 Cal. 2d 295, 379 P.2d 513, 29 Cal. Rptr. 33 (1963).

21. 68 Cal. 2d 728, 441 P.2d 912, 69 Cal. Rptr. 72 (1968).

22. In fact, Tobriner wrote the unanimous court of appeal decision. 379 P.2d 513, 29 Cal. Rptr. 33 (1962) (officially removed from publication). He was joined in that opinion by Justice Sullivan, who was appointed to the California Supreme Court in time to join in Dillon.

23. $68 \mathrm{Cal}$. $2 \mathrm{~d}$ at 748,441 P.2d at 925,69 Cal. Rptr. at 85 . The votes were as follows:

Amaya (District Court of Appeal)

For affirmance of granting of demurrer (0)

: none

For reversal of granting of demurrer (3)

: Tobriner, Sullivan, Bray

Amaya (Supreme Court)

For affirmance of granting of demurrer (4)

For reversal of granting of demurrer (3)

: Schauer, Traynor, McCoinb, White

: Peters, Gibson, Peek

Dillon (Supreme Court)

For affirmance of granting of demurrer (3)

For reversal of granting of demurrer (4)

: Traynor, Burke, McCounb

: Tobriner, Sullivan, Peters, Mosk

Justice Burke expressed displeasure in Dillon, noting "[e]very one of the argunnents advanced in today's opimion was considered by this court and rejected . . . in Amaya." Id. 


\section{a. Family Ties}

Generally, both trial and appellate judges disqualify themselves when they are related to someone connected to the case, whether it is a party, attorney, witness, or prior judge. ${ }^{24}$ Both the Cahifornia and federal statutes require disqualification if the relationship is within the third degree. ${ }^{25}$ This prong of disquahification is grounded im the natural affection and favoritism that a judge may be assumed to harbor for her relatives. Relationship to a party is a clear-cut case for disqualification. Like the case of judge-as-party discussed above, the absence of reported cases on the matter suggests its noncontroversy. ${ }^{26}$

Relationship to the attorney is more difficult. At common law, a judge was disquahified only when the related attorney was paid a contimgent fee. ${ }^{27}$ This scheme was based on the faulty premise that a judge would be partial only where her relative's pocketbook was affected. But her love for and pride in a relative seem as likely to imduce partiality. Recognizing this, the present statute calls for disqualification of the judge regardless of how the attorney is to be paid. ${ }^{28}$

But the statute gives no guidance on related but difficult questions of attorney/judge relationships. For example, if Justice Stanley Mosk must disqualify himself im cases argued by his son Richard, must he also disqualify himself where the case is argued by another member of his son's firm? ${ }^{29}$ Federal courts that have considered the question have

24. For the federal disqualifying statutes, see 28 U.S.C. $\& 455(\mathrm{~b})(5)(\mathrm{i})$ (1976) (party); 28 U.S.C. $\S 455$ (b)(5)(ii) (1976) (attorney); 28 U.S.C. $\$ 455$ (b)(5)(iv)(1976) (witness). The prior judge situation would likely fall under $\S 455(\mathrm{a})$ as a situation in which the reviewing judge's impartiality might reasonably be questioned. By contrast, Circuit Judge Learned Hand often reviewed decisions rendered by his cousin, District Judge Augustus Hand. See Frank, Disqualification of Judges, supra note 7, at 618 n.55.

For the California statutes, see CAL. CIv. Proc. Code \& 170(3) (West Supp. 1981) (party attorney). When the relation is to witnesses and prior judges, the situation is probably controlled by the general appearance of impartiality standard of CAL. Civ. PROC. CODE \& 170(5) (West Supp. 1981).

25. Cal. Civ. Proc. Code $\S 170(3)$ (West Supp. 1981); 28 U.S.C. § 455(b)(5) (1976). For variations in state practices, see Senate Hearings on $\mathcal{S}$. 1064, supra note 1, at 95-96 (statement of E. Wayne Thode).

26. Such a situation creates an overwhelming appearance of impropriety. See Frank, In Support of the Bayh Bill, supra note 1, at 46. It therefore raises fimdamental issues of due process. See note 10 supra.

27. Frank, Disqualification of Judges, supra note 7, at 616.

28. 28 U.S.C. $\$ 455(b)(5)(i i)$ (1976).

29. Administrative manageability is a concern here, which increases as law firms grow. For example, if the judge's son worked in an 100-attorney firm, instances of disqualification would be greatly inultiplied if the "relative in the firm" rule prevailed over the "relative only" rule. But the legislative history of 28 U.S.C. $\$ 455$ indicates only that a relative in the firm will not automatically disqualify the judge. Senate Hearings on S. 1064, supra note 1, at 96 (statement of E. Wayne Thode). See also Potashnick v. Port City Constr. Co., 609 F.2d 1101, 1112-14 (5th Cir. 1980).

However, Justice Mosk apparently lias a elear policy of disqualifyimg himself in all cases argued by his son's firm regardless of which attorneys in the firm participate. See, e.g., Interstate 
required withdrawal when the relative is a partner ${ }^{30}$ in the firm but not when he is an associate. ${ }^{31}$ Such reasoning is apparently based on the differing financial stakes that a partner has in a case as coinpared with an associate and is thus an unjustifiable throwback to the old common law standard whereby only a related attorney on a contingent fee inerited disqualification, a standard rightfully discarded.

\section{b. Professional Ties}

Judges coine to the bench froin a wide array of backgrounds and are likely to have developed inany close ties. These ties are often inore difficult to ineasure than family ties, since they may involve any acquaintances the judge has inade throughout her life, rather than just lineal ascendants or descendants. The professional link may be with one of several participants in the case-a party, an attorney, a law firm, an agency, or even with the subject inatter itself.

A prior professional tie with a party inay exist when a judge was counsel for the party on altogether different inatters before appointment to the bench. California statutorily prevents a judge froin sitting on a case if she was einployed as an attorney for any party within two years prior to commencelnent of the suit. ${ }^{32}$ The federal standard limits disqualification to situations where the judge acted as prior counsel in the case itself. ${ }^{33}$

Another type of prior relationship is one that persists even during the trial-when the party is another judge. ${ }^{34}$ In Mosk v. Superior

Brands v. Unemployment Ins. Appeals Bd., 26 Cal. 3d 770, 608 P.2d 707, 163 Cal. Rptr. 619 (1980) (no appearance by Richard Mosk); California Hotel and Motel Ass'n v. Industrial Welfare Comm'n, 25 Cal. 3d 200, 599 P.2d 31, 157 Cal. Rptr. 840 (1979) (appearance by Richard Mosk). Such disqualification creates the possibility of tactical abuse by litigants. When a party has taken an appeal to the supreme court on an issue on which the court will be divided closely, with Justice Mosk expected to vote against the party, he could assure Mosk's withdrawal by hiring his son's firm.

30. SCA Servs., Inc. v. Morgan, 557 F.2d 110 (7th Cir. 1977).

31. United States ex rel Weimberger v. Equifax, Inc., 557 F.2d 456 (5th Cir. 1977), cert. denied, 434 U.S. 1035 (1978) (no abuse of discretion where judge did not disqualify himself in case argued by firm in which his son was an associate, although financial interest provisions of statute might apply if sou were a partner).

32. Cal. Civ. Proc. Code $\S 170(4)$ (West Supp. 1981).

33. 28 U.S.C. $\$ 455(b)(2)$ (1976). Thus, disqualification was not requircd of District Judge Griesa in an antitrust action against General Motors solely because the firm for which he worked before appointment to the beuch had represented GM on unrelated nuatters. See National Auto Brokers v. General Motors Corp., 572 F.2d 953, 958 (2d Cir. 1978), cert. denied, 439 U.S. 1072 (1979). See also Carr v. Fife, 156 U.S. 494, 498 (1895).

34. A further puzzle is that forner judges may appear before the bench on which they sat without disqualificatiou ensning. See, e.g., The Slaughterhouse Cases, 83 U.S. (16 Wall.) 36 (1873) (argued by former Justice Campbell); Beecl1-Nut Packing Co. v. P. Lorillard Co., 273 U.S. 629 (1927) (argued by forner Chief Justice Hughes). But a former clerk may be forbidden from arguing before the court of his clerkship even though he has had close contact with only one judge of the court and the case has nothing to do with work done while a clerk. See SUP. CT. R. 7. 
Court, ${ }^{35}$ the California Supreme Court was faced with an appeal by its own Justice Stanley Mosk, contesting the validity of public hearings before the state Commission on Judicial Perforniance. Since the entire court was being investigated for alleged improprieties, six of the justices disqualified themselves from hearing Justice Mosk's appeal. Justice Newman, lowever, did not. ${ }^{36}$ In an unprecedented move, he was ordered disqualified by the six pro tem judges assigned to hear the appeal. ${ }^{37}$ It seeins reasonable that if judges may not participate in cases brought by recent clients, they certainly slould not do so in cases involving current colleagues.

Far more frequent are cases of prior relationships between a judge and members of the bar. Here, the practices vary widely. If the attorney and the judge are merely friends, even close friends, disqualification is not in order. ${ }^{38}$ Where the attorney and judge were law partners, disqualification is required only where the judge served as a lawyer in the matter at issue during the partnership. ${ }^{39}$

35. 25 Cal. 3d 474, 601 P.2d 1030, 159 Cal. Rptr. 494 (1979).

36. Justice Newman later defended his refusal to disqualify himself in an unpublished statement on Sept. 9, 1979, explaining that his actious were taken primarily because he had doubts as to the constitutionality of the ad hoc supreme court. The California Constitution provides for an ad hoc court when the Commission on Judicial Performance recommends censure, removal, or retirement of a supreme court justice, see CAL. Const. art. VI, § 18(c) (West Supp. 1981), but Mosk was not such a case. By refusing to withdraw, he hoped to force a decision on who should decide Mosk, before reaching the merits of the appeal. See Statement of Explanation by Frank C. Newman, Acting C.J. (Sept. 7, 1979) (on file with California Law Review). Instead, the temporary justices considered the validity of the ad hoc court and concluded that they had authority as a court to reach the merits of the suit. 25 Cal. 3d at 488, 601 P.2d at 1039, 159 Cal. Rptr. at 503.

37. See Olson v. Cory, 27 Cal. 3d 532, 568 n.5, 609 P.2d 991, 996 n.5, 164 Cal. Rptr. 217, 222 n.5 (1980) (Newman, J., dissenting) (The report of Olson that appears at 164 Cal. Rptr. 217 and at 609 P.2d 991 is actually the second of three versions of the case. The final official version, 27 Cal. 3d 532, has not been republished in the Califormia or Pacific Reporters. This Comment will cite the version at 164 Cal. Rptr. 217 and at 609 P.2d 991, although its techurical maccuracy should be kept in mind.). See also P. Stolz, Judging Judges: The Investigation of Rose Bird and THE CALIFORNIA SUPREME COURT 361-99 (1981); notes 117-21 and accompanying text infra.

38. See Frank, In Support of the Bayh Bill, supra note 1 at 49. But argument by certain close friends has led some judges to disqualify themselves. Frank, Disqualification of Judges, supra note 7 , at 622 . With the elimination of the federal duty-to-sit rule by the 1974 statutory amendment, disqualification because of friendship may become more prevalent. See H.R. REP. No. 93-1453, 93d Cong., 2d Sess. 5, reprinted in [1974] U.S. CodE CoNG. \& AD. News 6351, 6355. Cf. Firnhaber v. Sensenbrenner, 385 F. Supp. 406 (E.D. Wisc. 1974) (allegation that judge enjoyed close friendships with associates of defendant was insufficient to merit disqualification under old 28 U.S.C. § 455). In any case, if a judge's affection for family inembers merits disqualification, it is inconsistent to deny that such partiality inay exist toward close friends. The reason for treating the relationships differently is probably that it is easier to define who a judge's family members are than who her friends are.

39. 28 U.S.C. $\S 455(b)(2)$ (1976). See also Bumpus v. Uniroyal Tire Co., 385 F. Supp. 711, 714 (E.D. Penn. 1974) (allegation that judge was a law partner with plaintiffs counsel rejected as patently insufficient to require disqualification). Justice Black's controversial participation in Jewell Ridge Coal Corp. v. Local No. 6167, UMW, 325 U.S. 161, rehearing denied, 325 U.S. 897 (1945) (Jackson, J., concurring), where the attoruey was Black's law partner 20 years before trial, clearly 
Judges may also be connected with a case because of government service before appointment to the bench. ${ }^{40}$ Presently, a judge is forbidden from participating only when she took part in the actual case during her government service. ${ }^{41}$ Thus, an attorney general who later becomes a judge must disqualify herself only when she was actively connected with the case, as when she signed a pleading or had an active advisory role. ${ }^{42}$

Finally, a judge may be linked to the case by her legislative work on the issue. Neither the case law nor the statutes require disqualification for this relationship. Justice Black helped write the Fair Labor Standards Act when he was Senator Black, and upheld its constitutionahty years later in United States v. Darby. ${ }^{43}$ Similarly, Felix Frankfurter as professor helped draft the Norris-LaGuardia Act, and as Justice wrote an important opinion interpreting it. ${ }^{44}$

Thus, disqualification is called for in situations of prior professional ties when the judge worked on the specific proceeding while in private practice or in a government agency. Disqualification is required only in certain cases when the judge had some contact with either the chient or the attorney in private practice. The judge may participate if a former benchmate is arguing the case, or if she participated legislatively in the issue before the court.

\section{Financial Interest}

As noted above, financial interest in the outcoine of the case is the oldest known reason for a judge disqualifying herself. ${ }^{45}$ Issues of financial interest may arise when the judge is a shareholder or a ratepayer of a party or has some other incidental monetary stake in the

would be exonerated today. For a detailed account of the incident, concluding that Black did not act improperly, see Frank, Disqualification of Judges, supra note 7, at 605 n.2, 630-36.

40. Perhaps the most controversial recent instance of nondisqualification was Justice Rehnquist's participation in Laird v. Tatum, 408 U.S. 1 (1972). Testifying before a Senate subcommittee as assistant attorney general, when the appeal was pending, Rehnquist referred to Laird and expressed displeasure at a private citizen enjoining the government wiretapping involved in the case. He was widely criticized for sitting when Laird was later argued before the Court. He cast the key vote in a 5-4 affirmance of the government surveillance. See generally Laird v. Tatum, 409 U.S. 824, 826-27 (1972) (memorandum opinion of Justice Rehnquist); J. MACKenzIE, THE ApPEARANCE OF JUSTICE 207-23 (1974).

41. 28 U.S.C. $\$ 455(b)(3)$ (1976). Thus, the 1974 amendment should reverse decisions like Justice Rehnquist's, since he not only was a material witness in the proceeding but also expresed an opimion on the inerits of the case. See also Frank, In Support of the Bayh Bill, supra note 1, at $47-48,50$.

42. Senate Hearings on S. 1064, supra note 1, at 168 (Inemorandum prepared for Justice White upon his appointment to the Court and departure from the Department of Justice).

43. 312 U.S. 100 (1941).

44. United States v. Hutcheson, 312 U.S. 219 (1941).

45. See note 7 and accompanying text supra. 
outcome. $^{46}$

By far the most controversial relationship is the judge as shareholder. Under the earlier scheme, a judge had to determine whether she possessed a "substantial interest" in the company; only then was disqualification merited. ${ }^{47}$ Like California, the present federal standard demands disqualification no matter how small the holdings are. ${ }^{48}$ This has the definite advantage of clarity, but it is difficult to see why a judge who owns ten or twenty shares of AT\&T should automatically be branded as partial to AT\&T as a party. ${ }^{49}$

These rigid rules ${ }^{50}$ stand in contrast to the rules of subsidiary shareholdings or interests as ratepayers. The federal statute does not specifically cover the situation where the judge owns fifty shares of AT \& $\mathrm{T}$ and AT \& T owns fifty shares of $X$ Co., which is a party before the judge. ${ }^{51}$ However, where the judge is a ratepayer of a party such as the

46. Financial interest is rarely as blatant as it was in Tumey v. Ohio, 273 U.S. 510 (1927). There, the Supreine Court struck down a local ordinance which imposed fines for violations. The town inayor, who acted as judge, could recover his costs in each case, but only if he found the defendant guilty and assessed a sufficient fine. Id. at 519-20. Tumey makes clear that judges may not work on a commission basis.

47. Judicial Code and Judiciary Act, ch. 646, 62 Stat. 908 (1948) (current version at 28 U.S.C. $\$ 455$ (1976)). See also Senate Hearings on S. 1064, supra note 1, at 95, 102 (statement of E. Wayne Thode).

Just how the word "substantially" came to be inserted in the 1948 revision of the old disqualification statute is soinewhat of a mystery. See Senate Hearings on S. 1064, supra note 1, at 115 (stateinent of John P. Frank). Compare ch. 231, 36 Stat. 1090 (1911) with Judicial Code and Judiciary Act, ch. 646, 62 Stat. 908 (1948) (current version of both at 28 U.S.C. $\$ 455$ (1976)). In any case, defining the word in connection with stockholdings often proved to be difficult. Senate Hearings on $S$. 1064, supra note 1, at 95.

48. 28 U.S.C. $\$ \S 455(b)(4)$, (c)(4) (1976); Cal. C1v. Proc. Code $\$ 170(2)$ (West Supp. 1981). Under $\$ 455(\mathrm{~b})(4)$, holdings of the judge's spouse or minor children residing in her household are attributed to the judge. The new federal standards would reverse several results in older cases. See, e.g. , Lampert v. Hollios Music, 105 F. Supp. 3 (E.D.N.Y. 1952) (disqualification umecessary where judge held 20 of 13,881,016 shares of defendant RCA); Kinnear-Weed Corp. v. Humble Oil \& Ref. Co., 403 F.2d 437 (5th Cir. 1968), cert. dcnied, 404 U.S. 941 (1971) (same, where judge held 100 of $36,000,000$ shares of defendant Humble Oil \& Ref. Co.).

49. Such minor holdings in cases where Judge Blackmun sat were excused by the Senate during its investigation of him following his nomination to the Supreine Court. See Frank, Commentary on Disqualification of Judges-Canon 3C, 1972 UTAH L. REv. 377, 383 n.31 [liereinafter cited as Frank, Commentary on Disqualification].

50. Their rigidity may be simply an overreaction to the Haynsworth controversy. Clement Haynsworth was denied confirmation as a Supreme Court Justice largely due to his holdings in corporations that were parties to actious he heard. Frank, In Support of the Bayh Bill, supra note 1 , at 51-58.

51. By contrast, Senator Bayh's original proposal did attempt to deal with subsidiary holdmgs in this manner: a judge was disqualified either for holdings in a corporation which held $10 \%$ or inore of the shares of a corporate party or for holdings in a corporation of whose stock a corporate party held inore than $10 \%$. S. 1886, 92nd Cong., 1st Sess., $\$ 2$ (1971). The provisions were dropped apparently because they inet with disfavor at the Senate hearings. Senate Hearings on $S .1064$, supra note 1, at 16-18. Nevertheless, it can be argued that since securities held by a mutual fund in which the judge has an interest do not disqualify her, 28 U.S.C. $\$ 455$ (c)(4)(i) (1976), neither should small subsidiary holdings, especially since it is difficult for the judge to stay 
electric company, disqualification is demanded when this "other interest"s2 could be substantially affected by the outcome of the proceeding. ${ }^{53}$ These more flexible rules for ratepayers are not difficult to apply, but they do create a few paradoxes. For example, the Fourth Circuit held in In re Virginia Electric \& Power Co.$^{54}$ that Judge Warriner was wrong to disqualify himself in litigation that created the possibility that he, as a ratepayer, would receive a seventy to one hundred dollar rebate spread out over forty years on his electric bill. ${ }^{55}$ The court was correct to ignore such stakes as de minimis. The paradox is that had the judge purchased one share of the Virginia Electric \& Power Co., he would have been forced to disqualify himself, even if his financial interest was less than seventy dollars.

There have been other novel requests for disqualification where the judge has an uncertain or tangential financial interest, such as an interest in the publicity the case has brought to her, ${ }^{56}$ or a family tie to a person who has an indirect financial link to the action. ${ }^{57}$ These attempts have been generally unsuccessful. Thus, the law of disqualification for financial interest is marked by an absolute rule against shareholders but far more flexibility for ratepayers, subsidiary shareholdings, and other reinote interests.

\section{Personal Bias or Prejudice}

The type of disqualification most often invoked and most difficult

abreast of changing subsidiary holdings. But see Note, Disqualification of Judges and Justices in the Federal Courts, 86 HARv. L. Rev. 736, 753 (1973), where the author argues that disqualification should follow in all parent/subsidiary cases, although the practical problems are not considered.

52. Examples of other interests include a judge's status as ratepayer, taxpayer, or premium payer to an insurance company. Senate Hearings on S. 1064, supra note 1, at 103.

53. 28 U.S.C. $\$ 455(b)(4)$ (1976). Note that this section reincorporates the notion of "substantial interest" for indirect financial holdings, which inay entail the concomitant ills that led to its being discarded in connection with direct stockholdings. See note 47 supra.

54. 539 F.2d 357 (4th Cir. 1976).

55. The court found it significant that the words "however small" in the statute apphied to a tainting direct financial interest, but no such description applied to the "other interests that could be substantially affected" portion of 28 U.S.C. $\$ 455(b)(4)$ (1976). Having made this determination, it rejected Judge Warriner's interest as de minimis, concluding that a "reasonable inan would doubtless prefer a $\$ 2$ ticket at Churchill Downs on the first Saturday in May." Id. at 368. See also Gottlieb v. Department of Water \& Power, 110 Cal. App. 3d 505, 168 Cal. Rptr. 54 (2d Dist. 1980) (absent extraordinary circumstances, no disqualification is warranted where judge is creditor or debtor of government entity).

56. United States v. Haldeinan, 559 F.2d 31, 136-38 (D.C. Cir. 1976), cert. denied, 431 U.S. 933 (1977) (upholding Judge Sirica's refusal to disqualify himself in Watergate litigation although his name had become largely synonymous with it).

57. See United States v. Sellers, 566 F.2d 884 (4th Cir. 1977) (upholding Judge Chapman's participation in bank robbery case where his brother was chairman of the board and chief executive officer of the bank which was robbed). An analogous situation is where the judge's relative is a nonappearing partner in the law firm arguing the case. See notes 29-31 and acconpanying text supra. 
to prove is the allegation of personal bias or prejudice..$^{58}$ In many ways, bias is a category that encompasses all others, because knowledge, prior relationship, and financial interest may be viewed as reasons to assume that a judge harbors prejudice. Since no one is without behefs, ${ }^{59}$ the task is to measure when a judge's predispositions rise to such a level that a party cannot obtain a fair trial. Potential prejudices will be examined according to their objects: a party, a class of which a party is a member, an attorney, or the subject matter involved.

\section{a. Strict Personal Bias with Respect to a Party}

A judge may well have an opinion ${ }^{60}$ of a party in the litigation, but this does not automatically warrant disqualification. For example, if the opinion is formed by observation of the hitigant in the courtroom, any bias is not extra-judicially created and the judge may therefore contimue to sit. ${ }^{61}$ Even when a judge's opinion of a party developed entirely from a prior trial involvimg the same hitigant, disqualification is

58. Neither term is defined in the statute. 28 U.S.C. $\$ 144$ (1976) (applicable to district judges); 28 U.S.C. $\$ 455(b)(1)$ (1976) (applicable to all federal judges); CAL. Clv. Proc. Code $\$ \$ 170(5), 170.6$ (West Supp. 1981). Indeed, the entire case law inay amount to no more than an effort to define these slippery concepts. In its initial grappling with the notion, the Supreme Court equated bias with "the charge of a bent of mind that may prevent or impede impartiality of judgment." Berger v. United States, 255 U.S. 22, 33-34 (1921). For one effort in Califomia, see Pacific and S.W. Annual Conf. of the United Methodist Church v. Superior Court, 82 Cal. App. 3d 72, 86, 147 Cal. Rptr. 44, 52 (4th Dist., 1978) ("a predisposition to decide a cause or an issue im a certain way, which does not leave the mind perfectly open to conviction," quoting BLACK's LAW DICTIONARY).

59. We are born with predispositions; and the process of education, formal and informal, creates attitudes in all inen which affect thein in judging situations, attitudes which precede reasoning in particular instances and which, therefore, by definition are prejudices.... . Interests, points of view, preferences, are the essence of living. Only death yields complete dispassionateness.

In re J.P. Linahan, Inc., 138 F.2d 650, 651-52 (2d Cir. 1943). See also Andrews v. Agricultural Labor Relations Bd., 28 Cal. 3d 781, 790, 623 P.2d 151, 155, 171 Cal. Rptr. 590, 594 (1981). Cf. Laird v. Tatum, 409 U.S. 824, 835 (1972) (Relinquist, J., mem.) ("Proof that a Justice's mind at the time he joined the Court was a complete tabula rasa in the area of constitutional adjudication would be evidence of lack of qualification, not lack of bias.").

60. This section refers primarily to opinions of judges which disfavor a litigant or attorney. Such use comports with the general connotation of "bias" and "prejudice" and is also the overwhelming use of the term in the reported cases. However, it sliould be kept in mind that bias may equally refer to opinions that cause the judge to favor one party. For a novel allegation of this state of mind, see United States v. Gilboy, 162 F. Supp. 384, 394-97 (M.D. Pa. 1958) (Congressinan defendant Green atteinpted to disqualify ex-Congressinan Judge Murphy because the two had cominon backgrounds, were of similar religious, national and political persuasions, and Judge Murphy would overcompensate to show his integrity and lack of favoritism.).

61. See, e.g., United States v. Grinnell Corp., 384 U.S. 563, 583 (1966); United States v. Carignan, 600 F.2d 762, 763 (9th Cir. 1979); Huntingdon v. Crowley, 64 Cal. 2d 647, 661, 414 P.2d 382, 393, 51 Cal. Rptr. 254, 265 (1966); People v. Martinez, 82 Cal. App. 3d 1, 16, 147 Cal. Rptr. 208, 217 (5th Dist. 1978). 
not warranted. ${ }^{62}$ These standards serve to limit the cases of disqualification for personal bias to those where the judge knew the party either personally or by reputation before the trial began and, on the basis of that knowledge, harbored a bias against him. Since the party seeking to disqualify must prove special treatment, disqualification for personal bias is a rare occurrence. ${ }^{63}$

\section{b. Bias with Respect to Class of which Party is a Member}

Far inore common than the strict personal bias cases are those in which the judge may disfavor a party solely because he belongs to a particular class. A judge who has a strict personal bias dislikes the litigant because of who he is; here, her dislike stems more from what he is. Only when the judge's ill-feeling toward the group is sufficiently transferred to the individual litigant does disqualification follow, as in Berger $v$. United States, ${ }^{64}$ where the Supreme Court mandated disqualification of a trial judge who had made disparaging remarks in open court about German-Americans.

The statute requires a personal prejudice to disqualify, ${ }^{65}$ althougl Berger makes clear that the root of this personal prejudice inay be a class prejudice. No consistent standard has developed for deciding when a class prejudice constitutes a sufficient personal prejudice to mandate withdrawal. In United States v. Schreiber ${ }^{66}{ }^{6}$ Judge Knox, forinerly an attorney at the Interstate Commerce Commission (ICC), had

62. United States v. Goeltz, 513 F.2d 193, 198 (10th Cir.), cert. denied, 423 U.S. 830 (1975) (decision against defendant in another case does not show prejudice).

63. One such occurrence was in United States v. Brown, 539 F.2d 467 (5th Cir. 1976) (per curiam), where well-known defendant H. Rap Brown was tried for violations of the Federal Firearms Act. The trial judge had renarked to an attorney sone time before trial that he was presiding over defendant's trial and "that he was going to get that nigger." Id. at 468 . The Fifth Circuit had little trouble concluding that the renuark merited disqualification, and therefore reversed the conviction.

64. 255 U.S. 22 (1921). The defendants in Berger were German-Americans who were accused of violating the Espionage Act. They filed an affidavit to remove Judge Landis, alleging he had nuade the following stateinents in open court: "If anybody has said anything worse about the Germans than I have I would like to know it so I can use it. . . . One unust have a very judicial mind, indeed, not to be prejudiccd against the German Americans in this country. Their hearts are reeking with disloyalty." Id. at 28 . The Court held that the defendants' affidavit was sufficient to require disqualification of Judge Landis and reversed defendants' conviction and 20 year sentence.

65. 28 U.S.C. $\S \S 144,455(b)(1)$ (1976). Section 144 provides, in part:

Whenever a party to any proceeding in a district court inakes and files a timely and sufficient affidavit that the judge before whon the inatter is pending has a personal bias or prejudice either against him or in favor of any adverse party, such judge shall proceed no further therein but another judge shall be assigned to hear such proceeding.

Section $455(b)(1)$ provides that a judge shall disqualify himself "[w] here he has a personal bias or prejudice concerning a party or personal knowledge of disputed evidentiary facts concerning the procceding."

66. 599 F.2d 534 (3d Cir. 1979). 
expressed from the bench some opinions on the questionable veracity of trucking company presidents in ICC proceedings. ${ }^{67}$ Nonetheless, the Third Circuit upheld Judge Knox's participation where the defendant was charged with filing false statements with the ICC, because evidence of impersonal prejudice that derived from the judge's background was not a proper ground for disqualification. ${ }^{68}$ Schreiber and similar decisions ${ }^{69}$ have failed to recognize that the "personal bias" standard does not mean strictly personal bias, since class prejudices may suffice to meet the statute's test. ${ }^{70}$

Furthermore, proof of class prejudice is often difficult to gather. In Berger, the judge's class prejudices were blatant, but suppose Judge Landis had not stated in open court ${ }^{71}$ his intense ill-feeling toward Germans. The judge's prejudice would have had an equally deleterious effect on the trial, but the judge would not have been disqualified without more proof than mere rumors or gossip. ${ }^{72}$ The existence of such proof often depends on fortuitous circumstances. ${ }^{73}$ Thus, the scheme allows some actually prejudiced judges to avoid disqualification, with the result that the statute does not affect judges who are actually prejudiced as much as it affects those who appear to be. ${ }^{74}$

\section{c. Bias with Respect to Attorney}

In contrast to the treatment of a judge's bias toward a party, disqualification is not generally required when the judge dislikes only the

67. Id. at 538 .

68. Id.

69. See also Eisler v. United States, 170 F.2d 273 (D.C. Cir.), cert. granted, 335 U.S. 857 (1948), cert. dismissed per curiam, 338 U.S. 883 (1949). The judge in Eisler was not disqualified in the trial of an alleged Communist who had refused to testify before the House Un-American Activities Committee. The court said that neither the judge's prior involvement in FBI investigations of Communists nor his sponsorship of deportation legislation showed a sufficient personal bias against the defendant. $I d$. at 278.

70. California does not require personal bias. Cal. Clv. Proc. Code $§ 170(5)$ (West Supp. 1981). Thus, a judge's ill-feeling toward a class may be considered to be against the parties in an action. See, e.g., In re Adoption of Richardson, 251 Cal. App. 2d 222, 59 Cal. Rptr. 323 (2d Dist. 1967) (judge should have disqualified himself in proceedimg where deaf mutes sought to adopt a child, because he felt that deaf mutes as a class were not good parents).

71. The remarks actually were made at the sentencing stage of a different trial, not during the case at bar. 255 U.S. at 39 (Day, J., dissenting).

72. Id. at 34. Accord, United States v. Gilboy, 162 F. Supp. 384, 392 (1958).

73. Compare Eisler v. United States, 170 F.2d 273 (D.C. Cir.), cert. granted, 335 U.S. 857 (1948), cert. dismissed per curiam, 338 U.S. 883 (1949) (no disqualification at trial of communist who could only show circumstantially, as demonstrated by sponsorship of Communist deportation legislation, that judge disliked Communists) with Connelly v. United States Dist. Court, 191 F.2d 692 (9th Cir. 1951), rev'd on other grounds sub nom. Yates v. United States, 356 U.S. 363 (1958) (per curiam) (disqualification warranted when judge took trial attorney aside and said, "I am sorry to see you getting mixed up with the Commies. We must have another long talk.").

74. See notes 224-27 and accompanying text infra. 
party's attorney. ${ }^{75}$ Tales of judge/attorney conflicts are plentiful. One judge reportedly told an assistant United States attorney that he never wanted to see her in his courtroom again. ${ }^{76}$ Nonetheless, participation is permissible because "a judge may dislike and even distrust an attorney and yet be capable of doing exact justice towards his client."77 But if judges are actually capable of adopting complete professional detachment in spite of attorney bias, the same reasoning would seein to indicate that they could be equally professional when it comes to class bias. In addition, the disparate treatment of party and attorney bias is in stark contrast to the family relationship category discussed above: there, disqualification of the judge was equally mandated whether she was related to a party or his attorney. ${ }^{78}$

75. See, e.g., Davis v. Board of School Comm'rs of Mobile, 517 F.2d 1044, 1050-51 (5th Cir. 1975), cert. denied, 425 U.S. 944 (1976) (refusing to construe bias against attorney as being against party); United States v. IBM, 475 F. Supp. 1372, 1383 (S.D.N.Y. 1979), affd, 618 F.2d 923 (2d Cir. 1980). Contra, Bell v. Chandler, 569 F.2d 556 (10th Cir. 1978) (disqualification merited by Judge Chandler's repeated overdiscovery orders showing hostility toward prosecutor). While bias toward an attorney is not inentioned in 28 U.S.C. $§ 144$ or 28 U.S.C. $\$ 455$ (b) (1976), the reasonable lack of impartiality standard of $\S 455$ (a) might be invoked to deal with such conflicts. See United States v. Ritter, 540 F.2d 459, 464 (10th Cir.), cert. denied, 429 U.S. 951 (1976).

In California, the challenge for cause statute does not mention bias toward an attorney as requiring disqualification, but the peremptory challenge statute does allow such bias as grounds for challenge. Compare CAL. CIv. Proc. Code \& 170(5) (West Supp. 1981) with CAL. Civ. Proc. CODE $\S 170.6(1)$ (West Supp. 1981). In challenges for cause, then, the California standard is similar to the federal one. See, e.g., Shakin v. Board of Medical Examiners, $254 \mathrm{Cal}$. App. 2d 102, 118-19, 62 Cal. Rptr. 274, 287 (2d Dist. 1967), cert. denied, 390 U.S. 410 (1968) (bias toward attorney insufficient to merit disqualification, imterpreting $\S 170$ ).

Soine commentators have discussed cases in which the judge previously worked with the attorney as cases involving bias in favor of an attorney. See Frank, Disqualification of Judges, supra note 7, at 618-21. However, such cases involve no showing of actual favoritism, only the prior link. See notes 27-31 and accoinpanying text supra.

76. See Jones, Judge Hauk: Eccentricity in the Courtroom, Los Angeles Times, Dec. 29, 1980, at 1, col. 1. The following dialogue is reported between Judge Hauk and Assistant U.S. Attomey Theresa Kristovich:

Court: Shut up and sit down. I'm sick of you. I don't want to see you in my court again. Do you hear that?

Kristovicl: Yes, your honor.

Court: And you tell (chief assistant) Brosio that.

Kristovich: Yes, your honor.

Court: I've had you. I've given you every opportunity, but this is the end. I never want to see your face in my courtrooni again ....

Kristovich: Yes, your honor.

Court: . . . young lady. The minute I do, you're going to be thrown out. That's your punishment. Because you'll not listen to reason . . . .

Id. at 22. Judge Hauk relented several weeks later.

In a different matter, Judge Hauk refused a motion to disqualify based partly upon his hostility toward counsel. See Hayes v. National Football League, 463 F. Supp. 1174, 1178 (C.D. Cal. 1979).

77. Duplan Corp. v. Deering Milliken, Inc., 400 F. Supp. 497, 523 (D.S.C. 1975).

78. 28 U.S.C. $\S 455(b)(5)$ (1976). See notes $27-31$ and accompanying text supra. 


\section{d. Bias with Respect to the Subject Matter}

When judges decide cases, they actually decide issues; but a judge's feeling on the underlying issue in the case never warrants disqualification. ${ }^{79}$ This is not to suggest that a judge has the power to decide a case however she pleases, but merely to admit that a judge's mind, like any other mind, is subject to the laws of psychology ${ }^{80}$ Since what one sees in a situation is often a function of what one wants to see, ${ }^{81}$ bias with respect to the subject inatter of a case should be recognized as a potentially significant force. ${ }^{82}$

But the courts have long refused to acknowledge this type of bias. $^{83}$ Although the Tentative Draft of the ABA Code of Judicial Conduct called for disqualification when the judge had a "fixed behef concerning the merits of the matter," this language was eliminated froin the Fimal Draft. ${ }^{84}$ It was feared that inclusion in the Canons would create difficult questions in distinguishing a fixed belief in the merits from a fixed behef in the law applicable to a case. ${ }^{85}$

Thus, the law allows participation by a judge regardless of the $\mathrm{m}$ tensity of her emotions. An example is Lawton v. Tarr, ${ }^{86}$ a 1971 case

79. "The word bias refers to the mental attitude or disposition of the judge towards a party to the litigation, and not to any views that he may entertain regarding the subject matter involved." Andrews v. Agricultural Labor Relations Bd., 28 Cal. 3d 781, 790, 623 P.2d 151, 155, 171 Cal. Rptr. 590, 594 (1981) (quoting Evans v. Superior Court, 107 Cal. App. 372, 290 P. 662 (2d Dist. 1930). See also Senate Hearings on S. 1064, supra note 1, at 114 (statement of John P. Frank).

80. In re J.P. Linahan, Inc., 138 F.2d 650, 653 n.11 (2d Cir. 1943).

81. For an imteresting nonjudicial explication of this phenomenon, see T. KUHN, THE NATURE OF SCIENTIFIC REVOLUTIONS 62-64 (1962). Kuhn reports on experiments in which people were shown playing cards, several of which were anomalous, such as a black six of hcarts. At first, the subjects identified the anounalous cards without hesitation as either a six of hearts or a six of spades, showing the effect of expectation on perception. For an application of predictive decisionmaking theory based on issue preconceptions, see D. RohDE \& H. SPAETH, Supreme Court Decision MAKING 146-51 (1976).

82. See notes $200-15$ and accompanying text infra.

83. See, e.g., Henry v. Speer, 201 F. 869 (5th Cir. 1913) (fact that judge had stated a fixed opinion on the case to a newspaper before trial did not warrant recusal, since there was no personal bias); Cole v. Loew's Inc., 76 F. Supp. 872 (S.D. Cal. 1948), rev'd on other grounds, 185 F.2d 641 (9th Cir. 1950), cert. denied, 340 U.S. 954 (1951) (During a prior social engagement, Judge Yankwich had said that if an action were ever brought before him by a plaintiff who had been suspended from employinent due to investigation by the House Un-American Activities Committee, he would be coinpelled to find for the plaintiff; Judge Yankwich's participation in such a case was upheld.). A different result might follow under the appearance of partiality test under the present statute, 28 U.S.C. $\$ 455$ (a) (1976).

84. Compore ABA Canons of Judicial Ethics No. 2C(1) (Tent. Draft, May 1971) with ABA CODE OF Judicial CoNDUCT, Canon 3C. The Code is important because the reviscd federal statute was aimed at bringing statutory disqualification imto conforimity with the ABA Code. H.R. REP. No. 93-1453, 93d Cong., 2d Sess. 1-2, reprinted in [1974] U.S. Code CoNO. \& AD. NEws 6351, 6351 .

85. E.W. Thode, Reporter's Notes to the Code of Judiclal Conduct 61-62 (1973).

86. 327 F. Supp. 670 (E.D.N.C. 1971). 
involving the selective service and conscientious objector status. Judge Craven, in refusing to disqualify, asserted his ability to be impartial: "I do not believe that my strong aversion to the Vietnam War and my belief that it is the most tragic national mistake nade in iny lifetime will have the slightest effect or influence upon my judgment . . .."87 While the issue of disqualification was correctly decided under existing standards, the theory underlying participation in such circumstances repudiates most of the rest of disqualification law. It would be grossly inconsistent to allow participation by a judge who believes that an underlying element in the case was our inost tragic national mistake, and then, in the very next case before her, to demand disqualification because she owns one share of stock in a corporate party. ${ }^{88}$

Some litigants have attempted to impute subject inatter bias to the judge on a de facto theory - that is, some characteristic of the judge herself is used to suggest bias. For exainple, defendants in a class action einployinent discrimination suit brought by twelve blacks moved to disqualify Judge Higginbotham because he was black. ${ }^{89}$ In response, he wrote a lengthy and thoughtful inemorandum opimion explaining his refusal, pointing out that defendants' inotion related only to factors of his own background, not to the case. ${ }^{90}$ The theory of de facto bias has no place in disqualification law. Were it allowed so that nonblack defendants could successfully challenge a black judge, the black plaintiffs could use the saune theory to challenge any white judge assigned to the case. Such simphistic allegations of bias would reduce the judicial system to a shambles and have rightfully been given short shrift by judges so challenged. ${ }^{91}$

In suin, the rules for disqualification for bias have introduced the most difficult question in disqualification law: how human may a judge be and still be allowed to judge? The categories exannined have exhibited descending standards for disqualification: it is autonatic when proven bias exists against a party, likely when there is bias against the class to which a party belongs, unlikely when the bias is

87. Id. at 673 . Judge Craven offered evidence of his ability to reinain unbiased by citing his affirmances of death sentences despite his strong aversion to capital punishment. Id. at 672 .

88. Such inconsistencies will be further examined below. See notes 216-42 and accompanying text infra.

89. Pennsylvania v. Local 542, Int'l Union of Operating Eng'rs, 388 F. Supp. 155 (E.D. Pa. 1974).

90. Id, at 160 .

91. See, e.g., Paschall v. Mayone, 454 F. Supp. 1289, 1299-1301 (S.D.N.Y. 1978) (no disqualification in civil rights action solely because judge had been NAACP general counsel before elevation to the bench); Blank v. Sullivan \& Croinwell, 418 F. Supp. 1, 4-5 (S.D.N.Y. 1975) (no disqualification of feinale judge in sex discrimination suit against law firm); Deal v. Warner, 369 F. Supp. 174, 178 (W.D. Mo. 1973) (no disqualification of former naval officer judge in suit challenging inilitary laair-lengtl regulations). 
against the attorney, and unheard of if the bias concerns the ultimate issue involved in the case.

\section{B. Procedural Issues in Disqualification}

The inethod for disqualifying a judge is as important as the reason why the judge should be precluded from participating. ${ }^{92}$ Generally, courts have demanded strict comphance with apphicable procedures; otherwise the best reasons in the world for disqualifying a judge will not be considered. ${ }^{93}$ This section examines procedural issues of disqualification law through discussion of five basic questions: (1) Who raises the issue? (2) When inust it be raised? (3) Who decides it? (4) By what standards is it decided? and (5) What follows its determination?

\section{Who Raises the Issue?}

The California and federal standards for disquahification each consist of two separate statutes, and they differ as to who imitiates a challenge. A challenge for cause in California requires the trial or appellate judge to disqualify herself sua sponte if any of the enumerated grounds is present. ${ }^{94}$ If she fails to do so, the issue can be raised only by a party. ${ }^{95}$ By contrast, either a party or his attorney nay file a pereinptory challenge of a trial judge. ${ }^{96}$ Nowhere is the distinction explained, and the courts do not treat it as being critical. ${ }^{97}$

In federal courts, an affidavit of personal prejudice filed pursuant to section 144 can be filed only by a party, and affidavits filed by attorneys have been held to be fatally defective. ${ }^{98}$ Since the related statute, section 455 , contains no procedural component, disqualification pre-

92. For example, where a peremptory challenge exists, a litigant's motion need not state any substantive reason for disqualification. However, if it is not timely filed, the motion will be denied.

93. See, e.g., United States v. Clark, 398 F. Supp. 341, 362 (E.D. Pa.), affd without opinion, 511 F.2d 1396 (3d Cir. 1975) (possibilities of abuse require statute to be followed strictly); Solberg v. Superior Court, 19 Cal. 3d 182, 197, 561 P.2d 1148, 1158, 137 Cal. Rptr. 460, 470 (1977) (state courts have vigilantly enforced limits on timing and number of motions). However, courts often point out the procedural defects and then go on to reject the motion substantively as well. In such a case, it is unclear whether the motion is being denied solely on procedural grounds. See, e.g., Hawaii-Pacific Venture Capital Corp. v. Rothbard, 437 F. Supp. 230 (D. Hawaii), appeal dismissed, 564 F.2d 1343 (9th Cir. 1977); United States v. Clark, 398 F. Supp. 341.

94. Cal. Civ. Proc. Code § 170(5) (West Supp. 1981).

95. Id.

96. Cal. Civ. Proc. Code \& 170.6(2) (West Supp. 1981).

97. See, e.g., Shakin v. Board of Medical Examiners, 254 Cal. App. 2d 102, 62 Cal. Rptr. 274 (2nd Dist. 1967), cert. denied, 390 U.S. 410 (1968). Although the opinion notes that the filer of the inotion was plaintiff's attorney, it rejects the niotion primarily on the substantive ground that the bias alleged was insufficient to mandate disqualification. Id. at 118, 62 Cal. Rptr. at 286.

98. See, e.g., Paschall v. Mayone, 454 F. Supp. at 1300 (fact that counsel filed 28 U.S.C. $\S 144$ niotion is sufficient to warrant denial). Accord, Martelli v. City of Sonoma, 359 F. Supp. 
sumably is raised sua sponte by the judge. ${ }^{99}$ However, where the judge fails to step aside, a section 144 affidavit may be filed to raise the issues of disqualification mandated by section $455,{ }^{100}$ and, thus, the identical party rule applies. ${ }^{101}$ The strictness of the federal standard appears unjustified, because reasons for disqualification under section 455 are far more likely to be within the knowledge of the attorney than the party. The issue of disqualification should not turn upon whose signature appears at the end of the document; if the judge has any doubt as to the party's willingness to go along with the attorney's motion, she should return it for the party's signature, not reject it absolutely.

An important corollary issue to initiations of challenges arises when the judge suggests that the parties waive any objection to her hearing the case. ${ }^{102}$ The problem is that counsel may feel compelled to agree to the judge's suggestion. ${ }^{103}$ Hometown counsel are especially susceptible to this pressure, for they must appear continually before the same judges, and would not want to offend a judge who, in the spirit of full disclosure, has revealed a potential conflict of interest. If the judge did not beheve she could be impartial despite the potential conflict, she probably would not have suggested waiver.

\section{When Must the Issue be Raised?}

Because of the fear that motions to disqualify may be used for

397, 399 (N.D. Cal. 1973), affd without opinion, 556 F.2d 587 (9th Cir. 1977). In both cases, however, the court proceeded to examine the substantive violations alleged.

On the general federal statutory scheme, see note 5 supra.

99. Umited States v. Clark, 398 F. Supp. at 362 n.13.

100. See, eg., Hawaii-Pacific Venture Capital Corp. v. Rothbard, 437 F. Supp. 230, 234 (D. Hawaii), appeal dismissed, 564 F.2d 1343 (9th Cir. 1977). Sections 144 and 455 seem to travel in tandem. However, $\S 144$ refers only to personal bias against a party, which is but a small part of $\S 455$, namely $455(\mathrm{~b})(1)$. Thus, to apply its procedural provisions to all of $\S 455$ is a substantial stretch. Nonetheless, courts do make statements such as: "Section 144 sets forth the procedural requirements to be followed by a litigant seeking to disqualify a judge." Id. at 234 (emphasis added).

101. But the method for cliallenging appellate judges who refuse to step aside is a mystery. Section 144 does not apply because it is limited on its face to trial judges. Only $\S 455$ applies to appellate judges, and it contains no procedure for invocation. The substantive stretch of $\S 144$ (see note 100 supra) may be a procedural stretch as well.

102. This type of active waiver may be distinguished from the passive waiver which occurs when a party fails to meet the proper timing requirements of filing the motion to disqualify. See notes 104-11 and accompanying text infra. Both the California standard, CAL. CIV. PROC. CODE $\S 170(3)$ (West Supp. 1981), and the federal standard, 28 U.S.C. $\$ 455(e)$ (1976), allow waiver by the parties in limited circumstances.

103. Frank, Commentary on Disqualification, supra note 49, at 387. See also Senate Hearings on S. 1064, supra note 1, at 42, 115 (statement of John P. Frank). For an example of a waiver exchange in open court, see United States v. Conforte, 457 F. Supp. 641, 646 n.2 (D. Nev. 1978), modified on other grounds, 624 F.2d 869 (9th Cir), cert. denied, 100 S. Ct. 568 (1980). The waiver was held to be effective against defendant's post-trial motion that the judge should have disqualified himself. Id. at 655-56. 
purposes of delay, the statutes have strict timing requirements. With the formal abolition of court terms, ${ }^{104}$ the federal standard has been interpreted ${ }^{105}$ to require filing at the earliest moment after the facts meriting disqualification are discovered. ${ }^{106}$ Delay im filing the motion deserves harsli treatinent, because counsel inay use disqualification in a manipulative way: not raising the issue if the trial is going well, but filing the inotion if the litigant's prospects appear bleak. Thus, disqualification is properly denied when delay is apparent, ${ }^{107}$ although affidavits filed well before trial receive inore lemency regardless of the time elapsed between discovery of disqualifying facts and filing. ${ }^{108}$

Califorma's timing requirements are no less strict. A peremptory challenge must be filed five days prior to trial if the judge is known ten days before trial; otherwise, sucl motions must be made when the case is assigned for trial. ${ }^{109}$ Challenges for cause must be filed at the earliest practicable opportunity, or else are waived. ${ }^{110}$ Tluus, once the trial begins, a litigant's only metliod of disqualification is the challenge for cause, and it must be based upon recently discovered facts. ${ }^{111}$

\section{Who Decides the Issue?}

Once a motion to challenge is filed, decisions on its sufficiency and timeliness must be made. The Berger decision acknowledged the problein of allowing a judge to pass on the trutlufulness of an affidavit seeking leer own disqualification, but it nonetheless gave to ler the duty of passing on the affidavit's sufficiency. ${ }^{112}$ Thus, while noting its ills, Berger created a systein in the federal courts where the judge wlio is chal-

104. 28 U.S.C. $\$ 138$ (1976).

105. On its face, $\S 144$ requires that the affidavit be filed not less than ten days before the term at which the proceeding is to be heard. 28 U.S.C. $\S 144$ (1976). Generally, the $\S 144$ timing requirements liave been held to be equally applicable to $\$ 455$ challenges, although the latter does not contain its own timing procedures. See note 101 supra. See also Umited States v. Conforte, 457 F. Supp. at 654 n.7. But see SCA Servs., Inc. v. Morgan, 557 F.2d 110, 117 (7th Cir. 1977).

106. See, e.g., Umited States v. Gigax, 605 F.2d 507, 511 (10th Cir. 1979); United States v. Patrick, 542 F.2d 381, 390 (7th Cir. 1976), cert. denied, 430 U.S. 931 (1977).

107. Umited States v. IBM, 475 F. Supp. 1372, 1377-79 (S.D.N.Y. 1979), affd, 618 F.2d 923 (2d Cir. 1980) (efforts to disqualify Judge Edelstein in antitrust action seven years after start of suit held untimely); Rademacher v. City of Phoenix, 442 F. Supp. 27, 29 (D. Ariz. 1977) (affidavit untimely when allegations were known to plaintiffs years before filing).

108. See, e.g., Smith v. Danyo, 585 F.2d 83, 86 (3d Cir. 1978) (where facts relied upon in motion to disqualify oceurred in July and affidavit was filed in October, it was improper to reject the motion as untimely when trial was not scheduled to begin until December).

109. CAL. Civ. Proc. CODE $\$ 170.6(2)$ (West Supp. 1981). Also, the case must actually be assigned to a particular judge; assignment to a department is insufficient. Sce Bouchard v. Insona, 105 Cal. App. 3d 768, 772, 164 Cal. Rptr. 505, 507 (Ist Dist. 1980).

110. Shakin v. Board of Medical Examiners, 254 Cal. App. 2d at 115, 62 Cal. Rptr. at 285.

111. People v. Barger, 40 Cal. App. 3d 662, 669-70, 115 Cal. Rptr. 298, 302 (1st Dist. 1974).

112. 255 U.S. at 36. 
lenged has the power to deny the motion. ${ }^{13}$ In California, challenges for cause require a second judge, who is "not disqualified" from the proceeding, ${ }^{14}$ to pass on the allegation of bias with respect to the first judge. ${ }^{115}$ Peremptory challenges allow the challenged judge to pass on the timeliness of the motion only. ${ }^{116}$

In addition to having the challenged judge or another judge resolve the issue of disqualification, a third potential technique would be to let the other judges on a court collectively disqualify one of their benchnrates. This dangerous precedent was adopted by the ad hoc California Supreme Court in Mosk v. Superior Court, ${ }^{117}$ when four of the six court of appeal justices appoimted by lot disqualified Justice Newman without opinion. ${ }^{18}$ There is obviously a procedural impasse when a member of the supreme court refuses to disqualify himself, simce there is practically no opportunity for appeal. ${ }^{119}$ However, the ad hoc court members in Mosk not only acted without authority, they also created a precedent for the judges of a court to unite to disqualify one of their own, perhaps for no more than policy disagreements. As one justice put it, "[t]he very thought of such an awesome power is frightening." 120 The ad hoc court should have followed the course of the

113. For the problems a judge has in limiting her review of the affidavit to sufficiency, see notes 127-31 and accompanying text infra.

Some federal judges, realizing the poor appearance created by the Berger standard, have sua sponte transferred a challenge of themselves to another judge to pass on sufficiency. See, e.g., United States v. Grinnell Corp., 384 U.S. 563, 582 n.13 (1966) (District Judge Wyzanski referred the question of his disqualification to the chief judge of the First Circuit); Martelli v. City of Sonoma, 359 F. Supp. 397, 398 n.1 (N.D. Cal. 1973), affd without opinion, 556 F.2d 587 (9th Cir. 1977) (district judge referred question to district's chief judge, who assigned it to another district judge).

114. It is unclear by what standards this derivative disqualification is measured. When judges seek advice from their peers on the bench in close cases of disqualification, see Frank, Disqualification of Judges, supra note 7, at $612 \mathrm{n} .25$, Judge 2 might have personal knowledge of the facts of the controversy, a situation that might mandate withdrawal. See note 8 and accompanying text supra. Or Jndge 2 may well have an interest in the subject of disqualification of her fellow judges, and such interest may require disqualification under CAL. CIv. Proc. CoDE $\$ 170(1)$. Or a higant might contend Judge 2 has a bias that disqualifies her from passing on the partiahty of her benchmate under $\S 170(5)$. Such a theory could be carried on ad infinituin. If $P$ sues corporation $D$ and $P$ moves to disqualify Judge 1 , must Judge 2 disqualify herself if she owns stock in $D$ ? The question, then, is whether Jndge 2's disqualification is based on $P$ v. $D$ or $P$ v. Judge 1 .

115. Cal. Civ. Proc. Code $\S 170(5)$ (West Supp. 1981).

116. See McCartney v. Commission on Judicial Quahifications, 12 Cal. 3d 512, 531-32, 526 P.2d 268, 282, 116 Cal. Rptr. 260, 274 (1974).

117. 25 Cal. 3d 474, 480 n.2, 601 P.2d 1030, 1034 n.2, 159 Cal. Rptr. 494, 498 n.2 (1979).

118. See notes 35-37 and accompanying text supra. See also Olson v. Cory, 27 Cal. 3d 532, 568 n.5, 597-603, 609 P.2d 991, 996 n.5, 1022-24, 164 Cal. Rptr. 217, 222 n.5, 249-51 (1980) (Newman, J., dissenting and Annexes J-L).

119. The only possible appeal in a situation like Mosk is a due process appeal to the U.S. Supreme Court. See note 10 supra.

120. Dissenting opinion of Justice Hopper, reprinted in Olson v. Cory, $27 \mathrm{Cal}$. 3d at 602, 609 P.2d at 1024, 164 Cal. Rptr. at 250-51. Simce it takes a inajority to disqualify a judge, the disquali- 
Supreme Court in Jewell Ridge Coal Corp. v. Local 6167, UMW,121 where the Justices noted they had no power to exclude one of their duly appoimted members.

\section{By What Standards is the Issue Decided?}

The determination of the issues alleged im a petition for disquahifcation may be decided along a continuum of standards: at one end is the peremptory challenge, the lightest standard of review; in the middle is the present federal test, a sufficiency of facts approach; finally, at the other end is the mini-hearing, an ex parte determination of the merits of the motion made by a second judge.

The peremptory challenge requires no allegation of specific facts warranting disqualification, but merely a belief by the party or attorney that a fair trial cannot be had before the assigned judge. ${ }^{122}$ If the affdavit meets the timing requirements, the judge must step aside and the master calendar judge will reassign the case. ${ }^{123}$

By contrast, the federal standard requires the challenged judge to examine the contents of the affidavit. The facts upon which the claim for disqualification is based must be stated with particularity. ${ }^{124}$ The judge has no opportunity to respond to the charges; she must accept them as true. ${ }^{125}$ So accepted, if they are sufficient to convimce a reasonable mind that bias exists, she inust withdraw. ${ }^{126}$

fication obviously will not affect the outcome of a particular case; however, it may affect whether there is a dissent or whether the decision is published.

121. 325 U.S. 161, rehearing denied, 325 U.S. 897, 897 (1945) (Jackson, J., concurring).

122. Cal. Civ. Proc. Code $\S 170.6(2)$ (West Supp. 1981). For the theory that the statute requires belief of prejudice rather than prejudice in fact, see Solberg v. Superior Court, $19 \mathrm{Cal}$. 3d 182, 193, 561 P.2d 1148, 1155, 137 Cal. Rptr. 460, 467 (1977). The California standard is the model for recent proposals for federal peremptory challenges. See note 1 supra.

123. Most courts have $\S 170.6$ forms, and the attorney or party need only fill in the blanks to make a successful challenge. See People v. Hunter, 71 Cal. App. 3d 634, 643 n.3, 139 Cal. Rptr. 560, $564 \mathrm{n} .3$ (2d Dist. 1977) (Hanson, J., dissenting). A model form is provided in the statute. Cal. Civ. Proc. Code $§ 170.6(5)$ (West Supp. 1981).

124. See, e.g., Berger v. United States, 255 U.S. at 34; United States v. Haldeman, 559 F.2d 31, 134 (D.C. Cir. 1976), cert. denied, 431 U.S. 933 (1977) (facts stated must be definite as to time, place, persons, and circumstances).

125. The only control on sham pleadings is the requirement of good faith certifications by counsel. Because only a party nay initiate a challenge under 28 U.S.C. $\$ 144$, couusel appears to be put in the difficult position of having to make a good faith certification of the client's good faith. Also, there is hittle threat of serious enforcement; although one early case mentioned disbarment, such drastic neasures are not used. See Nations v. United States, 14 F.2d 507, 509 (8th Cir.), cert. denied, 273 U.S. 735 (1926).

126. Section 144 could be read hiterally as being intended to provide a peremptory challenge. "Wheuever a party ... makes and files a timely and sufficient affidavit that the judge before whoin the inatter is pending has a personal bias . . . such judge shall proceed no further therein, but another shall be assigned to hear such proceedings." 28 U.S.C. $§ 144$ (1976) (emphasis added). See also Fong v. American Airlines, Inc., 431 F. Supp. 1334, 1336 (N.D. Cal. 1977), affd, 626 F.2d 759 (9th Cir. 1980). Legislative history lends support to this construction, particularly the 
The major problem with this standard is the difficulty of passing on the sufficiency of facts without making an assumption as to their 1nerits, especially where the judge feels the sting of a personal attack. ${ }^{127}$ For example, in United States $v$. Hanrahan, ${ }^{128}$ the plaintiff alleged that Judge Sirica had threatened to lock him up if he did not plead guilty. ${ }^{129}$ Judge Sirica denied the motion to disqualify:

The . . . allegation is not only untrue, but also ridicnlous. It is inconceivable that any sane and reasonable mind could believe that such a statement was made especially since the Court has no power to lock up a defendant in order to coerce a plea of guilty . . . . Nonetheless, assuming that such a statement was made, and construing it strictly, as is required, the Court holds it to be legally insufficient. ${ }^{130}$

There is little doubt that the allegations were untrue; lowever, had they been true, disqualification certainly would have been required. ${ }^{131}$

The third standard that may be used to resolve disqualification issues is the mini-hearing on an affidavit's allegations, whicl is used in challenges for cause in California. ${ }^{132}$ Such affidavits must set forth the charges with particularity, ${ }^{133}$ and the challenged judge has ten days to file her answer, setting forth additional facts if necessary. Another judge then passes upon the truthfulness of the allegations im the affidavits and may order disqualification if the allegations appear true and

debate over the predecessor to $\$ 144$. See 46 CoNG. REc. 2627 (1911) (judge has no discretion in deciding whether to step aside once an affidavit is submitted). In fact, when Senator Bayh proposed his peremptory challenge measure in 1971, its language was strikingly similar to the already existing $\$ 144$. See S. 1886, 92 d Cong., 1st Sess., § 3 (1971). Nevertheless, case law has grafted the sufficiency of facts test onto the statute. See, e.g., Berger v. Umited States, 255 U.S. at 34; United States v. Ritter, 540 F.2d 459, 462 (10th Cir.), cert. denied, 429 U.S. 951 (1976).

127. The House Report on revisions to $\$ 455$ noted that disqualification was a "sensitive question." H.R. REP. No. 93-1453, 93d Cong., 2d Sess. 5, reprinted in [1974] U.S. CODE CoNG. \& AD. NEws 6351, 6355. In addition, district judges often treat the matter in a somewhat bitter tone. See, eg., Duplan Corp. v. Deering Milliken, Inc., 400 F. Supp. 497, 502 (D.S.C. 1975) ("[T]his matter raises the question of whether this or any court can allow itself to be coerced by a powerful but dissatisfied law firm.").

128. 248 F. Supp. 471 (D.D.C. 1965), affd sub nom. Tynan v. United States, 376 F.2d 761 (D.C. Cir.), cert. denied, 389 U.S. 845 (1967).

129. Id. at 477.

130. Id.

131. Judge Sirica attempted to justify his conclusion by arguing that the statements did not show extra-judicial bias. This is a generous reading of the extra-judicial requirement, for it was not meant as an absolute shield against disqualification for any activity that happens to occur im the courtroom. For example, Judge Landis' outburst against German-Americans in Berger occurred in the courtroom, but this did not prevent his disqualification. See notes 64-65 and accompanying text supra.

132. Cal. Civ. Proc. Code $§ 170(5)$ (West Supp. 1981).

133. When the motion makes only conclusions or vague charges, the challenged judge may properly exclude the motion and proceed as if it had not been filed. See People v. Sweeney, 55 Cal. 2d 27, 35, 357 P.2d 1049, 1053, 9 Cal. Rptr. 793, 797 (1960). However, this judicial gloss has not been extended as far as the sufficiency of facts standard in the federal scheme. Sce notes 12426 and accompanying text supra. 
they would preclude a fair and impartial trial. Thus, this is the only one of the standards that actually involves determining the truth or falsity of the allegations. The advantage of such a determination is that disqualification will generally be based on true allegations; the disadvantage, however, is the increased use of scarce judicial resources that the imini-hearing requires. ${ }^{134}$

\section{What Follows Determination of the Issue?}

Challenges of judges raise collateral problems, whether or not the challenge succeeds. When a challenge is unsuccessful, either because the judge is vindicated after a mini-hearing or because she rules that the affidavit is insufficient or untimely, a dehcate situation arises: she returns to hear the case itself, irritated or insulted by the challenge. ${ }^{135}$ Even unintentionally, such irritation nay be expressed through subtle retribution throughout the trial. ${ }^{136}$

Even when the challenge is successful, problenis remain. The new judge nuay be even worse in the party's mind, but the allowable peremptory challenge has been exhausted. ${ }^{137}$ Furthernnore, the process of assignment of judges raises serious questions, including the possibility that the assignor may exhibit bias in choosing the replacement judge. ${ }^{138}$ In fact, the case inay even be transferred by the successfully challenged judge to one of her colleagues. ${ }^{139}$ Thus, the result of a successful dis-

134. But see note 174 and accompanying text infra.

135. See note 127 supra.

136. The fear of retribution is the major reason why proceedings before the Commission on Judicial Performance are ordimarily confidential. Otherwise, lawyers or court personnel could risk retribution, especially where the judge is exonerated. P. STOLz, supra note 37, at 391. A related fear is that the vindicated judge will overcompensate in her attempt to be fair to the unsuccessful challenger. Such efforts to exclude bias may themselves be unjust. See In re J.P. Limahan, Inc., 138 F.2d 650, 652 n.10 (2d Cir. 1943).

137. While the litigant can challenge for cause after using his peremptory challenge in California, the federal system has a strict limit of one challenge per case. See, e.g., United States v. Hoffa, 245 F. Supp. 772 (E.D. Tenn. 1965), affd, 382 F.2d 856 (6th Cir. 1967), cert. denied, 390 U.S. 924 (1968). However, because the new 28 U.S.C. $\S 455$ substantively subsumes $\S 144$, the new judge should still disqualify himself under $\$ 455(b)(1)$ even if the party is technically forbidden from filing a second affidavit under \& 144. See notes 5, 99 \& 100 supra.

138. One recent study of pro tein assignments to the Califorma Supreme Court found that $87 \%$ of the votes cast by an assigned judge were identical to the votes cast by the assigning judge in the same case. Comment, The Selection of Interim Justices in California: An Empirical Study, 32 Stan. L. Rev. 433, 437 (1980). Chief Justices Gibson, Traynor, and Wright relied primarily on retired justices to sit pro tem, and choosing froun such a small group may explaim the voting correlation. Chief Justice Bird generally has assigned current state judges from all levels to sit temporarily on the high court. See P. STOLZ, supra note 37, at 105-07. In fact, the percentage of total days of assistance supplied by retired judges has dropped sharply since Chief Justice Bird took office. See Judicial Council of California, AnNual Report of the Administrative OfFICE of THE CALIFORNIA CourTs 109 (1980) (heremafter cited as ANNUAL RePORT).

139. United States v. Torbert, 496 F.2d 154, 156-57 (9th Cir.), cert. denied, 419 U.S. 857 
qualification petition is not necessarily the fresh and disinterested judge that the litigant sought.

This Comment has examined both the substance and procedure of disqualification law. Substantively, inconsistencies abound under the present system. ${ }^{140}$ Furthermore, federal practice is marred by a theoretical tension that exposes the lack of a consistent basis for disqualification standards. ${ }^{141}$ Procedurally, the federal practice of allowing the challenged judge to pass upon the sufficiency of the affidavit is unreliable. ${ }^{142}$ In the wake of these problems have come the federal proposals for peremptory challenges, to which the next section of this Comment is addressed.

II

\section{The Merits of the Peremptory Challenge System}

The appeal of the peremptory challenge lies chiefly in its simplicity. It discards all of the substantive inconsistencies in the present federal system discussed above by establishing a system of one automatic challenge per side per case. ${ }^{143}$ It thus follows the nodern trend of making disqualification easier. ${ }^{144}$

Such a system, however, is not without its costs. California's pereinptory challenge system has been the target of many abuses. ${ }^{145}$ Experience casts doubt on the argument that the risk of offending a judge ${ }^{146}$ and the uncertainty of the identity of the replaceinent judge ${ }^{147}$ will

(1974). But cf. CAL. Crv. Proc. Code § 170(5) (West Supp. 1981) (disqualified judge may request another judge to take over the case only if the new judge is acceptable to the parties).

140. See notes $52-55,73 \& 77$ and accompanying text supra.

141. See notes 86-88 and accompanying text supra.

142. See notes 127-31 and accompanying text supra.

143. See H.R. 1649, 97th Cong., 1st Sess. $\$ 2$ (1981). Indeed, one could argue that the peremptory challenge delays rather than solves the problems of the present system. Once a party has used his peremptory challenge, he inust revert to a challenge for cause if he fears bias in the replacement judge.

144. Senate Hearings on S. 1064, supra note 1, at 33 (statement of John P. Frank).

145. In upholding the validity of $\$ 170.6$, the California Supreme Court proceeded on the assumption that the charges of abuse were true. Solberg v. Superior Court, 19 Cal. 3d 182, 195, 561 P.2d 1148, 1156, 137 Cal. Rptr. 460, 468 (1977). Chief Justice Wright reported in 1971 that the statute presented a serious problem in scheduling operations, basing his conclusions on a study by the Judicial Council. See Judicial Council of California, Peremptory Challenge of JUDGES-C.C.P. $\$ 170.6$ (1969), reprinted in Senate Hearings on $S$. 1064, supra note 1, at 52-57. The report includes the inconsistent results of a survey of trial courts. Asked whether $\$ 170.6$ was used properly, 69 out of 134 courts agreed that it was and only 46 said it was not (the rest having no opinion). However, only 27 out of 134 responses said the system was "not abused." The difference seems to suggest that soine judges beheve that $\S 170.6$ is properly used as an abuse mechanism. See also, Court Improvement: Hearings on Disqualification of Judges Before the California Assembly Committee on the Judiciary 65 (Dec. 11, 1979) (hereinafter cited as Court Improvement Hearings); Select Committee on Trial Court Delay, Report 6, 53-54 (1972).

146. See Solberg v. Superior Court, 19 Cal. 3d at 196, 561 P.2d at 1157, 137 Cal. Rptr. at 469.

147. See note 155 infra. 
cause counsel to refrain from exercising the pereinptory challenge. In addition, the self-restraining potential of peremptory challenges is sharply reduced in large counties, where an attorney nay practice infrequently before the saine judge; ${ }^{148}$ also, an out-of-county lawyer would have no qualms about challenging even sinall county judges, especially if he is not likely to appear again in the saine county. ${ }^{149}$

From a inore theoretical perspective, reliance on an automatic limitation of abuses appears misplaced. It is certainly a novel proposition that a method should be favored because it is not abused as inuch as it might be. The focus instead sliould be on the incidence and control of existing abuses. Such abuses are not adequately prevented by the judicial gloss that requires pereinptory challenges to be filed in good faith. ${ }^{150}$ The presence of soine abuse suggests that the systein is not working, not that it is working well because it could be abused nore.

Probleins created by the pereinptory challenge systein can be grouped into four categories: (1) encouragement of judge-shopping; (2) judicial waste; (3) personal affront to the challenged judge; and (4) the appearance of justice. ${ }^{151}$

148. For example, there are 202 superior court judges in Los Angeles County. The National Law Journal, Apr. 27, 1981 at 12, col. 1. Six other counties in Cahfornia have inore than 20 superior court judges. See ANNUAL REPORT, supra note 138, at 128-29.

149. Thus, in complex cases in small counties involving both local and out-of-county counsel, the local counsel can supply the judge-shopping knowledge and the out-of-county counsel can be the sacrificial movant because of his slight risk of reappearance.

150. See McCartney v. Commission on Judicial Quahifications, 12 Cal. 3d 512, 538 n.13, 526 P.2d 268, 286 n.13, 116 Cal. Rptr. 260, 278 n.13 (1974). Good faith appears to be an ineffective control because, first of all, judge-shopping challenges can be made in good faith. See note 154 and accompanying text infra. Secoud, evidence indicates that most trial court judges feel the system is abused. See note 145 supra. The good faith requirement was disparaged by Judge Watt before the Assembly Judiciary Committee, when he stated that $\S 170.6$ motions were insufficient proof of good faith because they are "only a piece of paper." Court Improvement Hearings, supra uote 145 , at 61 .

151. The peremptory challenge also casts doubt on the duty-to-sit rule-that a judge has as much a duty to sit when not disqualified as she has to withdraw when disqualified. See, e.g., Laird v. Tatum, 409 U.S. 824, 837 (1972) (Rehnquist, J., mem.). The 1974 federal statutory revision makes the rule's continued vitality for federal judges questionable. See H.R. REP. No. 93-1453, 93d Cong., 2d Sess. 5, reprinted in [1974] U.S. CODE CONG. \& AD. NEwS 6351, 6355. In California, trial judges are so easily disqualified that their duty to sit is questionable. Although Justice Newman has recently asserted that appellate judges have a duty to sit, see Olson v. Cory, $27 \mathrm{Cal}$. 3d 532, 566, 609 P.2d 991, 1010, 164 Cal. Rptr. 217, 246 (1980) (Newman, J., dissenting), his benchmates apparently do not share that philosophy. See, e.g., J.R. Norton Co. v. Agricultural Labor Relations Bd., 26 Cal. 3d 1, 603 P.2d 1306, 160 Cal. Rptr. 710 (1979) (Chief Justice Bird, who helped create the state Agricultural Labor Relations Act, declined to participate in interpreting the Act); Tex-Cal Land Mgmt., Inc. v. Agricultural Labor Relations Bd., 24 Cal. 3d 335, 595 P.2d 579, 156 Cal. Rptr. 1 (1979) (Chief Justice Bird would not sit on case peripherally involving the Agricultural Labor Relations Board, where issue was the constitutionality of the standard of review for state agency findings). See also note 29 supra. Abandonment of the duty to sit could eveu lead to overdisqualification, that is, the use of disqualification to avoid harsh public reaction to controversial cases. See, e.g., Judges Get Transfers in Busing Case, The National Law Journal, Apr. 27, 1981, at 12, col. 1. See also Olsou v. Cory, 27 Cal. 3d at 595, 609 P.2d at 1021, 164 Cal. 


\section{A. Judge-Shopping}

Judge-shopping occurs when a judge is challenged because her predispositions, prior rulings or reputation seein to oppose a litigant's interests. ${ }^{152}$ It is widely recognized to be the most common abuse of peremptory challenges. ${ }^{153}$ In fact, the statute arguably has made judgeshopping a duty of the conscientious attorney ${ }^{154}$ by allowing disqualification upon belief that the judge is biased against the interest of a party. Under sucls a standard, challenges might not be used to get rid of a prejudiced judge, but rather to find one who is inore favorably inclined toward the litigant. ${ }^{155}$

An example of these tactics occurred in Solberg $v$. Superior Court. ${ }^{156}$ There, Judge Marie-Victoire had dismissed several criminal prostitution complaints because slie felt the defendants were victims of discriminatory law enforcement, as none of their male customers were arrested. ${ }^{157}$ On the next day, three inore accused prostitutes were brought before Judge Marie-Victoire, and the district attorney, cognizant of the prior day's rulings, filed a peremptory challenge. The judge refused, claiming the motion was based sub silentio only on her prior dismissals, but the refusal was ultimately reversed. ${ }^{158}$ Even broader than the issue-specific challenge of Judge Marie-Victoire are the blan-

Rptr. at 257 (newspaper account of Chief Justice Bird's denial of recusal motion in case considermg validity of Proposition 13). But $\mathcal{~ f f . ~ P . ~ S T o l z , ~ s u p r a ~ n o t e ~ 3 7 , ~ a t ~} 71$ (reporting Chief Justice Bird's disqualification in habeas corpus decision of In re Caudillo, 26 Cal. 3d 623, 610 P.2d 1021, 164 Cal. Rptr. 692 (1980), largely beause her concurrence in the origimal Caudillo case had beconie a controversial issue in the campaign to oust her from office in November 1978).

152. See Solberg v. Superior Court, 19 Cal. 3d at 194, 561 P.2d at 115, 137 Cal. Rptr. at 467.

153. Fraijo v. Superior Court, 34 Cal. App. 3d 222, 230, 109 Cal. Rptr. 909, 914 (2d Dist. 1973) (Compton, J., concurring and dissenting). See also Senate Hearings on S. 1064, supra note 1 , at 54 (survey of California judges revealed judge-shopping the most frequent abuse of $\S 170.6$ ).

154. As one attorney put it, "[J]udge shopping . . . can be a dirty word. It can also be an appropriate method of being an advocate, which is what we are paid to be and what we take an oath to be." Court Improvement Hearings, supra note 145, at 72 (testimony of Peter Mills). Even Assemblyman Fenton, chairman of the committee, echoed the sentiment: "[S]ome judges are tough sentencers. I practice criminal law, and if I'm going to do the best for nuy client, and I can get rid of that judge, I've got to do my job." Id. at 70 .

155. The game is also a gamble, since party and attorney never know who the new judge will be. The gamble would have especially high stakes when the second toughest sentencer has been drawn as the judge, because to challenge her risks exposure to the real hard-liner waiting in the wings.

156. 19 Cal. 3d 182, 561 P.2d 1148, 137 Cal. Rptr. 460 (1977).

157. Id. at $194 \mathrm{n} .11,561$ P.2d at $1156 \mathrm{n} .11,137 \mathrm{Cal}$. Rptr. at $468 \mathrm{n} .11$.

158. There were other complications along the way. When Judge Marie-Victorie refused to withdraw despite the $\$ 170.6$ motion, the district attorney sought a writ of mandate in the superior court to compel her disqualification. Defendants in the underlying criminal action then moved to disqualify the new judge assigned to hear that motion. He refused to disqualify himself, but ordered Judge Marie-Victoire to disqualify herself. The suprcme court untangled the facts, upheld $\S 170.6$, and resolved the dispute by deciding that both refusals were improper. Id. at 204, 561 P.2d at 1162, 137 Cal. Rptr. at 474. 
ket challenges of particular judges that occasionally have been filed by both public defenders and district attorneys. ${ }^{159}$ Though the California Supreme Court has disapproved of this practice, ${ }^{160}$ no effective enforcement mechanisms against its use exist. ${ }^{161}$

The opportunity for judge-shopping should not be respected as a right for several reasons. First, it highhights the fact that justice may vary according to the particular judge. Such an emphasis is counterproductive in a systen 1 concerned with the appearance of justice. ${ }^{162}$ Second, judge-shopping unay create problenıs in judicial administration, especially where blanket challenges of the "toughest" judges render them unable to help reduce the court's caseload. Finally, judgeshopping is nothing nore than forun1-shopping within the same forum, and therefore it fosters the sanie nranipulative evils that has led the Supreme Court to vigorously oppose forum-shopping. ${ }^{163}$

\section{B. Judicial Waste}

Especially in smaller counties, the filing of a peremptory challenge may result in judicial waste and excessive delay, because the trial is put off until a temporary out-of-county judge can be brought in to preside. ${ }^{164}$ Delay can benefit either the party, who nray be out on bail, or the attorney, who niay be unprepared. ${ }^{165}$ Even large counties niay face similar problenıs when word gets around that only one judge is cur-

159. See McCartney v. Commission on Judicial Qualifications, 12 Cal. 3d 512, $538 \mathrm{n} .13,526$ P.2d 268, 286 n.13, 116 Cal. Rptr. 260, 278 n.13 (1974). See also Senate Hearings on S. 1064, supra note 1, at 52 (California Judicial Council Report that two Alameda County Superior Court judges were disqualified repeatedly by public defender and district attorney).

160. Solberg v. Superior Court, 19 Cal. 3d at 203-04, 561 P.2d at 1162, 137 Cal. Rptr. at 474.

161. Blanket challenges of certain judges reduce the peremptory challenge to an empty formality. When cases are assigned to the targeted judge, slie is challenged without discretion. When the replacement judge is assigned, she may be challenged only for cause, since the statutory limit of one per case has been exhausted. Furthermore, even when the targeted judge is not assigned to the case, counsel may hesitate to use the peremptory challenge out of fear that the targeted judge will be assigned to the case as the second judge. Thus, the policies behind permitting peremptory challenges are undermined.

162. See notes 193-215 and accompanying text infra.

163. See, e.g., Deposit Guar. Nat'1 Bank v. Roper, 100 S. Ct. 1166, 1174 (1980); Hanna v. Plumer, 380 U.S. 460, 467-68 (1965).

164. Solberg v. Superior Court, 19 Cal. $3 d$ at 195, 561 P.2d at 1156, 137 Cal. Rptr. at 468 . The 1969 Judicial Council Report suggested the statute be modified to require the movant to certify that the motion was not made for purposes of delay, but no action was ever taken on the proposal. Besides the delay to the particular trial, a judge's time and the state's money are lost in bringing an out-of-county judge in to hear the case. These expenses might not be incurred if the challenger were unable to use a peremptory cliallenge.

165. Court Improvement Hearings, supra note 145, at 63 (testimony of Maynard Craig, criticizing last-minute challenges by attorneys who "stayed home and watched football while 1 was working"). A literal reading of the statute may even provide a haven for the unprepared attorney, since his tardimess may create a good faith belief that his chent "cannot have a fair trial" before the assigned judge. 
rently available for trial. ${ }^{166}$ Under the California master calendar system, a case is not assigned a judge until the morning of the trial. ${ }^{167}$ Ordinarily, when party or counsel lodges a peremptory challenge, the case will be reassigned immediately. Opportunities for delay are therefore greater in smaller counties with fewer replacement judges.

California's statute clearly forbids using the peremptory challenge as a dilatory tactic. ${ }^{168}$ This is a wise policy, for delay of even a single case in a master calendar system crowds the next day's calendar. ${ }^{169}$ In practice, however, it is more difficult to control delay. ${ }^{170}$ The result is judicial inefficiency, for when blanket challenges are used against a particular judge ${ }^{171}$ or when the last available trial judge is repeatedly challenged by successive attorneys, she is effectively forestalled from helping to reduce backlog. ${ }^{172}$ Thus, when peremptory challenges are employed to delay trial, they squander already scarce judicial resources.

Furthermore, while it is true that the procedures for adjudicating challenges for cause under section $170(5)$ are far niore cumbersome, ${ }^{173}$ it does not necessarily follow that using the easier peremptory challenge will conserve judicial resources. In the nidividual case this may be true, but it should not be assumed that most of the present pereinptory challenges would still be filed if section 170(5), with its time-consuming procedures, were the only available avenue. However, it can be expected that fewer peremptory challenges of the judge-shopping variety would be filed if supporting facts were required to be included in

166. Id. at 65 (testimony of Stanley Collis).

167. Cal. Ct. R. 223. See also Judicial Council of California, Master-Individuat Calendar Study 2 (1974) (letter to Chief Justice Wright) [hereinafter cited as Calendar STUDY].

168. Cal. Civ. Proc. Code $§ 170.6(4)$ (West Supp. 1981).

169. Where individual calendar systems are used, opportunities for delay are fewer under the 10-day/5-day rule: where the judge is known to the parties 10 days before trial, a $\$ 170.6$ motion inust be made at least 5 days prior to the trial. CAL. Civ. Proc. Code $\S 170.6(2)$ (West Supp. 1981). However, a 1974 study concluded there was no reason to inore toward individual calendars, as have the federal courts. See CALENDAR STUDY, supra note 167, at 2 (letter to Chief Justice Wright).

170. See, e.g., Los Angeles County Dep't of Pub. Serv. v. Superior Court, 69 Cal. App. 3d 407, 138 Cal. Rptr. 43 (2d Dist. 1977) (\$170.6 inotion held timely even though filed immediately after unsuccessful motion to continue).

171. See notes 159-61 and accompanying text supra.

172. Any system which even marginally contributes to backlog ought to be severely restricted, given the scope of the problem in California. As of 1979, for example, there were 71,179 civil cases awaiting trial in Los Angeles County Superior Court alone. See ANNUAL Report, supra note 138 , at 81 .

173. See notes 132-33 and accompanying text supra. But see Court Improvement Hearings, supra note 145, at 67 (testimony of Stanley Collis, arguing that the "hearings" conteinplated by $\S 170(5)$ are often ex parte determinations by another judge and therefore consuine little tiune). 
the affidavit. ${ }^{174}$ Thus, in the broader perspective, the peremptory challenge is not the champion of efficiency it is touted to be.

\section{Personal Affront to Judges}

Unquestionably, the major concern of our judicial system is to dispense justice to litigants, not to soothe hard feelings that judges may have about disqualification. Nonetlieless, when a judge is unjustifiably made the target of motions which reflect on her professional pride and abilities, such feelings ought to be exammed. They may create a rift between the bench and the bar, ${ }^{175}$ with the result that litigants will suffer. Inquiry, therefore, demands recogmition of the emotional strams and inadequacies that afflict judges along with the rest of the species. As Judge Frank put it nearly forty years ago: "Much harm is done by the myth that, merely by putting on a black robe and taking the oath of office as a judge, a man ceases to be human and strips himself of all predilections, becomes a passionless thinking machine."176

From the perspective of the judge, the peremptory challenge can represent intense frustration. Not only is she told that she is imcapable of being fair to a party, she is never given the opportunity either to hear what substantiates such a charge or to air her side of the conflict. The reaction to this frustration may sometimes be overt anger. ${ }^{177}$ On other occasions, she may refuse to participate in an obvious misuse of the peremptory challenge. ${ }^{178}$ And while the most common reaction is a

174. According to Stanley Collis, Executive Officer of the Superior Court of Alameda County, if peremptory challenges were not permitted, "I don't think you're going to find an increase in $170(5)$. I think that the 170.6 will just go away . . . I don't think they're real challenges." Court Improvements Hearings, supra note 145, at 67.

175. See generally Slonim, supra note 1. But cf. Senate Hearings on S. 1064, supra note 1, at 15 (Seuator Baylh argued that his proposed pereinptory challenge would not create ill-feeling among judges, because the allegation of bias is clearly pro forma).

176. In re J.P. Linahan, Inc., 138 F.2d 650, 652-53 (2d Cir. 1943). See also id. at 653 n.11.

177. See McCartney v. Commission on Judicial Qualifications, 12 Cal. 3d 512, 523 n.8, 526 P.2d 268, 276 n.8, 116 Cal. Rptr. 260, 268 n.8 (1974). The complaint against Judge McCartney was based in part on the following admonition he delivered to the public defender after being the repeated target of pereinptory challenges:

If you think I'n going to take away the dignity of this Court and what the people elected ine to do, then you're out of your mind.

-. I'in not going to be pushed around by the Public Defender's Office and the abuse and the perversion that they have engaged theinselves in emasculating an elected official of the people.

...

... This thing is being abused badly, and I'm not about to stand for it, and I'll fight it every time, every place, every corner where justice will permit ne to do it.

Id. at 525 n.8, 526 P.2d at 277 n.8, 116 Cal. Rptr. at 269 n.8.

178. See discussion of Solberg v. Superior Court, 19 Cal. 3d 182, 561 P.2d 1148, 137 Cal. Rptr. 460 (1977) at notes 156-58 supra. 
professional detachment by which the judge simply accepts her challenged fate, even here, an emotional scar may be inflicted. ${ }^{179}$ In all three cases, the possibility of subliminal reprisals in future cases must be acknowledged. Thus, far from avoiding the problem of unintentional retribution thought to exist in the challenge for cause system, ${ }^{180}$ the often-abused peremptory challenge creates a potentially greater risk of subliminal reprisals at future trials. ${ }^{181}$

When potential personal imsults to judges are unavoidable on the route toward justice, they must be accepted as a cost of doing justice. But they are not unavoidable in disqualification. Without the free rein permitted parties and attorneys under a peremptory challenge system, the judge at least would be apprised of the facts upon which a challenge is grounded. Where response is permitted, ${ }^{182}$ she has less reason to feel emotional frustration. Because peremptory challenges provide no opportunity to confront or respond, not only is there greater potential for future reprisal, but these reprisals may be inore severe than those following an unsuccessful challenge for cause. ${ }^{183}$ The risk should not be overstated, but neither should it be denied, ${ }^{184}$ and alternatives that would diffuse the risk should be preferred. ${ }^{185}$ Peremptory chal-

179. Judge Reginald Watt recently testified before the California Assembly Judiciary Committee:

When a 170.6 is filed . . the attorneys think that the judges don't pay any attention to that and don't care. That's what they'll say im public, but you get into the privacy or in conversations at a cocktail lounge [where one judge told me], "Look, if a judge wasn't prejudiced before a 170.6, he sure as hell is afterwards."

Court Improvement Hearings, supra note 145, at 62.

180. When a judge is unsuccessfully challenged for cause, she returns to hear the case and may harbor a grudge which surfaces at the trial. See notes 135-36 and accompanying text supra. The peremptory challenge is thought to avoid this problem because there are no unsuccessful peremptory challenges. This is maccurate, because the challenged judge passes on the timeliness of the motiou, see note 116 and accompanymg text supra, so that the problem exists to the extent that the motions are denied as untimely filed. Even where the motion is timely filed, the problem is only delayed until the next time the attorney appears before the challenged judge.

181. In a pereinptory challenge system, there probably will be more judges challenged. With judges being challenged more frequently, there is a greater likelihood of judicial hostility that could be expressed by subliminal reprisals at trial, particularly when judges feel that peremptory challenges are abused. See note 145 supra.

182. See, e.g., Cal. Civ. Proc. Code $\S 170(5)$ (West Supp. 1981).

183. In addition, at least with challenges for cause there should be some evidence of a good faith belief of bias, since some facts must be alleged in support of the motion. That consideration may assuage a judge's wrath.

184. The fear of offending the judge and incurring subtle reprisals in subsequent appearances is the major reason why $\$ 170.6$ challenges are used far less often in sunall counties. There, counsel must be concerned with frequent future appearances before the same judge. See Court $I m$ provement Hearings, supra note 145, at 69 (testimony of Augustus Noland).

185. A comparison to the peremptory challenge of jurors is not convincing support for peremptory challeuges of judges. Professor Babcock has suggested three policy justifications for jury challeuges: first, its legitimizes the jury in the mind of the litigant because the jury "belongs" to him sincc he chose it; second, it avoids trafficking im common stereotypes; and third, it is a shield for exercise of the clralleuge for cause. Babcock, Voir Dire: Preserving "Its Wonderful Power," 27 
lenges operate to muzzle the judge, allowing charges against her to be treated as if they were true, and thereby grant her far less due process protection than we would provide for a litigant. ${ }^{186}$

Another aspect of this is the notion that the peremptory challenge is better because it allows challenges to be made without einbarrassing accusations about the judge. ${ }^{187}$ However, while it avoids the problem of embarrassing accusations, the peremptory challenge also allows imdefensible standards such as de facto bias ${ }^{188}$ to be used as the grounds for disqualification. For example, under a peremptory challenge system, Judge Higgmbotham could have been excluded froin hearing an employment discrimination suit solely because he was black. ${ }^{189}$ Judge Motley could have been challenged successfully in a sex discrimination suit solely because slie was female. ${ }^{190}$ And Judge Sirica would never have heard the Watergate trials because of his interest in the publicity the case had brought him. ${ }^{191}$ These are not ineritorious reasons for disqualification and any procedure which defers to them ought to be resisted. ${ }^{192}$ Thus, the avoidance of einbarrassing accusations inust be balanced agamst the inability to detect improper bases for disqualifica-

STAN. L. REv. 545, 552-55 (1975). All of these policies are inapposite to the judicial peremptory challenge. First, rather than lend legitinacy to the process of choosing a judge, the sole judicial peremptory challenge turns the replacement of a judge into a gamble. See notes 196-99 and accompanying text infra. Second, our system assumes that a judge is less apt to engage in typical biases than are jurors. See, e.g., FeD. R. Evid. 403 and CAL. Evid. CoDE $§ 352$ (West 1966) (judge is trusted to rule against adınissibility of certain evidence due to its prejudicial effect on jurors). Also, the statutory reasons for challenging a juror for cause are broader than those for challenging a judge for cause. Compare CAL. Clv. Proc. CODE $\S 170$ (West Supp. 1981) (judges) with Cal. Civ. Proc. Code $\S 602$ (West Supp. 1981) (jurors). Fimally, the argument that the peremptory challenge protects the use of the challenge for cause rests on the theory that a potential juror may become so offended by the examination of his thoughts and background that, even though no grounds for a challenge for cause are discovered, the juror should still be eliminated due to hostility created by the process. There is no sinilar investigative process in judicial challenges for cause and, therefore, this arguinent would not apply.

186. See, e.g., U.S. Const. ainends. V, VI and XIV \& 1 .

187. See, e.g., Solberg v. Superior Court, 19 Cal. 3d at 199-200, 561 P.2d at 1159, 137 Cal. Rptr. at 471 . Presuinably, the allegations referred to fall in the class of personal bias, since it is the inost sensitive branch of disqualification, and also because the facts necessary to allege personal knowledge, prior relationship, or financial interest do not reflect a judge's mental processes and are consequently less personal. It is less einbarrassing for all parties to exclude a judge quickly rather than review allegations that she harbors a bias against a group or individual.

188. See notes 89-91 and accompanying text supra.

189. See Pennsylvania v. Local 542, Int'l Union of Operating Engineers, 388 F. Supp. 155 (E.D. Pa. 1974).

190. See Blank v. Sullivan \& Croinwell, 418 F. Supp. I (S.D.N.Y. 1975).

191. See United States v. Mitchell, 377 F. Supp. 1312 (D.D.C. 1974), affd sub nom. United States v. Haldeman, 559 F.2d 31 (D.C. Cir. 1976), cert. denied, 431 U.S. 933 (1977).

192. Cf. Andrews v. Agricultural Labor Relations Bd., 28 Cal. 3d 781, 800, 623 P.2d 151, 161 62, 171 Cal. Rptr. 590, 600-01 (1981) (Newinan, J., concurring) (stating that California law has never countenanced challenges for de facto bias, yet failing to consider that fear of de facto bias underlies peremptory challenges). 
tion that peremptory challenges allow. A peremptory challenge system would jettison substantive standards and would countenance arbitrary and capricious misuses.

\section{The Appearance of Justice}

Justice Frankfurter once wrote that justice must satisfy the appearance of justice. ${ }^{193}$ This concept underlies many of the justifications of the peremptory challenge. ${ }^{194}$ Unfortunately, "appearance of justice" and "public confidence in the courts" are phrases that are laudable in print but shippery in practice. ${ }^{195}$ Analysis of the appearance of justice involves questioning how mipartial a judge can be and what reasonable expectations of impartiality a litigant nay have. In short, what must be examined are the practical abilities and limitations of a judge. ${ }^{196}$

Before examining such limitations, the assumption that the appearance of justice is fostered by peremptory challenges can be attacked. Such challenges may act paradoxically to reduce a litigant's confidence in the system. When a litigant is allowed to remove a judge without stating his reason, he may conclude that the state has acknowledged that justice will vary according to the judge. This is a dangerous path to travel. When hitigants are prompted to focus on variations between judges-as they are by the peremptory challenge because they are allowed one chance to find a "better" judge-litigants may conclude that their success in the judicial system is arbitrary, a function of which judge hears the case. Such a conclusion would decrease rather than increase confidence in the judiciary.

Additionally, if justice does vary according to the judge, then the arbitrary limit of one peremptory challenge per side is unjustified. ${ }^{197}$ Consider the criminal defendant who "loses" in the peremptory challenge gamble: ${ }^{198}$ the judge originally assigned to the case is reputed to be a tough sentencer ${ }^{199}$ and is peremptorily challenged, but the replace-

193. Offutt v. United States, 348 U.S. 11, 14 (1954).

194. Solberg v. Superior Court, 19 Cal. 3d at 193 \& n.10, 561 P.2d at $1155 \&$ n.10, 137 Cal. Rptr. at 467 \& n.10.

195. For example, Judge Martin T. Manton of New York once petitioned the Supreme Court to review his criminal conviction on the grounds that convicting judges of crimes destroyed public confideuce in the courts. See J. MACKENZIE, supra note 40, at 227.

196. Cf. Ross v. Bernhard, 396 U.S. $531,538 \mathrm{n} .10$ (1970) (referring to the practical abilities of jurors).

197. Cal. Civ. Proc. Code $\S 170.6(3)$ (West Supp. 1981). Not only does the one challenge per side rule appear arbitrary, but a litigant can have his chance to exercise a peremptory challenge foreclosed solely because a nonadverse co-party has already made such a motion. $C f$. Avital v. Superior Court, 114 Cal. App. 3d 297, 170 Cal. Rptr. 588 (2d Dist. 1981).

198. See note 155 supra.

199. In California, a judge's reputation among the bar is the most likely reason to file a peremptory challenge. Most courts assign judges according to a master caleudar system. See CaLENDAR STUDY, supra note 167 . Thus, an attorney or party has no real opportunity to researcli the 
ment judge is a tougher sentencer. Further opportunities to challenge by the same procedure are not permitted. This does not instill a belief that justice is being served. Rather, it provokes an attitude that the legal system is a game in which gambles may be taken, gaunbles that may fail.

What sort of impartiahty does a hitigant have the right reasonably to expect in a judge? It carmot be the total absence of preconceptions, for that condition is unknown in humans. ${ }^{200}$ Yet cases still refer to disqualification as a method of finding judges whose minds adhere to the "straight line of impartiality."201 Such assertions are mythological. The most that we may reasonably ask of the judicial mind is to make a special effort to be aware of the existence of leanings or preconceptions and to ignore them whenever possible.

Examples of bias are legion. Chief Justice Warren voted in favor of the government in fifty-nine out of sixty antitrust cases argued during one period. ${ }^{202} \mathrm{~A}$ similar bent of mind characterized the pro-taxpayer votes repeatedly cast by Justice Douglas in the latter part of his tenure on the Court. ${ }^{203}$ Over a period of two and a half years ending in November 1980, Chief Justice Bird voted to sustain or allow damages in eighty-seven percent of the civil negligence actions that reached the court; 204 Justice Clark voted against damages in ninety-three percent of those cases. $^{205}$ How are such rcsults squared with the appearance of justice? They should not be cause for a crisis of confidence in the court, for they simply reveal consistent and predictable human behavior as shaped by preconceptions, ${ }^{206}$ and hint of a judge's practical limitations.

Furthermore, despite deference to stare decisis, courts have occasionally overruled decisions for no apparent reason other than a change in personnel. A particularly spirited volley is exhibited in the cases of

potential biases of the assigned judge, since the challenge must be lodged immediately upon assignment under $\$ 170.6(2)$.

200. 'If, however, 'bias' and 'partiality' be defined to mean the total absence of preconceptions in the mind of the judge, then no one has ever had a fair trial and no one ever will." In re J.P. Limahan, Inc., 138 F.2d 650, 651 (2d Cir. 1943). See also note 59 supra.

201. Pacific and Sw. Annual Conf. of the United Methodist Church v. Superior Court, 82 Cal. App. 3d 72, 87, 147 Cal. Rptr. 44, 53 (4th Dist. 1978).

202. Frank, In Support of the Bayh Bill, supra note 1, at 48 n.27.

203. Wolfman, Silver \& Silver, The Behavior of Justice Douglas in Federal Tax Cases, $122 \mathrm{U}$. PA. L. REv. 235, 237 (1973). The authors report that during one period, Justice Douglas cast protaxpayer votes in $73 \%$ of the cases while the Court sustained the taxpayer's position in only $17 \%$ of those cases. Id. at 332 .

204. Kahn, The Bird Court: How Liberal Is It?, 12 CAL. J. 69, 70 (1981).

205. Id.

206. See Lawlor, Personal Stare Decisis, 41 So. CAL. L. REv. 73, 80-84 (1968). The author proposes a model whereby traditional stare decisis principles are modified to take into account the judge hearing the case. See also notes 80-81 and accolnpanying text supra. 
Schwalbe v. Jones ${ }^{207}$ and Cooper v. Bray, ${ }^{208}$ decided two years after Schwalbe. Both cases considered the constitutionality of California Vehicle Code section 17158, which forbade a passenger from suing the permissive driver of a car owned by the passenger. In the California Supreine Court's original decision in Schwalbe (Schwalbe I), ${ }^{209}$ the provision was declared unconstitutional. Shortly thereafter, the suit by owner-passenger Cooper against driver Bray went to the jury, and the trial judge did not instruct on Vehicle Code section 17158, assuming its unconstitutionahty under Schwalbe $I$. After a verdict against Bray was returned, a rehearing on Schwalbe $I$ was granted. ${ }^{210}$ Upon rehearing, the supreine court reversed itself and upheld the proscribing statute in Schwalbe $I I{ }^{211}$ Defendant Bray then appealed, because the instructions in his trial were based on the defunct rule of Schwalbe $I$. On appeal, the high court reversed Schwalbe II, returning to Schwalbe I, largely due to the votes of three of its new members. ${ }^{212}$ Justice Richardson dissented in Bray: "No new legal developments have occurred which would alter, or challenge, our Schwalbe [II] analysis. . . . The issues and the arguinents remam identical. Only the faces have changed."213

These examples are offered only to show that notions such as the appearance of justice must be tempered with an acknowledgement of the huinan limitations of judges. ${ }^{214}$ Indeed, the notion provides an inadequate standard upon which to base a system of disqualification for

\footnotetext{
207. 16 Cal. 3d 514, 546 P.2d 1033, 128 Cal. Rptr. 321 (1976).

208. 21 Cal. 3d 841, 582 P.2d 604, 148 Cal. Rptr. 148 (1978).

209. 534 P.2d 73, 120 Cal. Rptr. 585 (1978) (officially removed from publication).

210. Cooper v. Bray, 21 Cal. 3d at 846, 582 P.2d at 606, 148 Cal. Rptr. at 150.

211. Schwalbe v. Jones, 16 Cal. 3d at 525, 546 P.2d at 1040, 128 Cal. Rptr. at 328.

212. The voting was as follows:

Schwalbe I (1975)

Unconstitutional (4) : Tobriner, Mosk, Burke, McComb

Constitutional (3): Sullivan, Wright, Clark

Schwalbe II (1976)

Unconstitutional (2) : Tobriner, Mosk

Constitutional (5): Sullivan, Wright, Clark, McComb, Richardson

Cooper (1978)

Unconstitutional (5) : Tobriner, Mosk, Bird, Manuel, Newman

Constitutional (2) : Clark, Richardson
}

Jnstice Richardson replaced Justice Burke between Schwalbe $I$ and Schwalbe II. Justice McComb's abrupt switch is inexplicable, although his mental state at the time is uncertain. See McComb v. Commission on Judicial Perfonnance, 19 Cal. 3d Spec. Trib. Supp. 1, 564 P.2d 1, 138 Cal. Rptr. 459 (1977). Three new appoimtments were made between Schwalbe II and Cooper.

213. Cooper v. Bray, 21 Cal. 3d at 856, 582 P.2d at 613, 148 Cal. Rptr. at 157 (Richardson, J., dissenting). $C f$. National League of Cities v. Usery, 426 U.S. 833 (1976) (the Burger Court holding that Congress cannot set minimum wages for state government employees, overruling the Warren Court's contrary holding im Maryland v. Wirtz, 392 U.S. 183 (1968)).

214. Andrews v. Agricultural Labor Relations Bd., $28 \mathrm{Cal}$. 3d at 791, 623 P.2d at 156, $171 \mathrm{Cal}$. Rptr. at 595. 
several reasons. First, emphasis on the appearance of justice reinforces the inaccurate notion that judges are automatons who may toe the straight line of impartiality. Second, no good explanation can be offered the litigant as to why he has a free challenge in trial court but must accept an appellate panel unless he can challenge a judge for cause. Third, rhetoric about the appearance of justice is simply discarded in the cases with the worst appearances of all-those in which judges pass on issues relating to their own salaries. ${ }^{215}$ Finally, it is impossible to define what the appearance of justice may be to society or to any hitigant. In fact, to the ordinary litigant justice may only be synonymous with prevailing.

When litigants have good reasons to challenge judges, they should certainly be permitted to do so. The mechanism for such a fact-based charge is the challenge for cause. Peremptory challenges are inadequate because they promote a view of the judicial process as one akin to roulette. Additionally, they permit such abuses as delay and judgeshopping. Public confidence in the judiciary is served by none of these mevitable side effects. On balance, then, the recent federal proposals for peremptory challenges would create more problems than they would solve. As an alternative, the next part of this Comment suggests a rethinking of the theoretical basis of disqualification law.

III

\section{UnTANGling Disqualification STandards}

Modern law on disqualification suffers from inconsistencies that show the absence of a sound theoretical base. The system demands disqualification of a judge when she owns a smgle share of stock im a corporate party, ${ }^{216}$ yet allows participation when she consistently votes protaxpayer or proconsumer. ${ }^{217}$ The problem requires a rethinking of the proper goals of disqualification law and an integration of substantive grounds for withdrawal with procedural devices.

\section{A. Rethinking Disqualification Law}

A major difficulty with disqualification law is that it is usually thought of as a series of independent reasons why a judge should withdraw. This is due primarily to an awkward—even backward-histori-

215. Under the rule of necessity, where the litigant would be left without a forum because all judges should disqualify themselves in certain cases, none is disqualified. See United States v. Will, 101 S. Ct. 471, 479 (1980); Olson v. Cory, 27 Cal. 3d at 537, 609 P.2d at 994, 164 Cal. Rptr. at 220. However, judges do withdraw from such cases, even after the rule of necessity has been invoked. For example, Justice Blackmun took no part in Will; both Chief Justice Bird and Justice Tobriner withdrew from Olson.

216. See notes 47-49 and accompanying text supra.

217. See notes 202-05 and accompanying text supra. 
cal development. Blackstone declared that the law will not suppose the possibility of bias or favor in a judge. ${ }^{218}$ Thus, even though pecuniary interests were grounds for disqualification at common law, ${ }^{219}$ it was viewed as a situation distinct froin bias, rather than an example of it. ${ }^{220}$ As the common law grew, new reasons for disqualification, such as family relationships, emerged and were added to the body of disqualification law in a list-like fashion. When, in this century, bias emerged as a disqualifying standard, ${ }^{221}$ it was dutifully added to the list.

In fact, bias should have been heading the hist, for our judicial system and notions of due process presuppose the existence of an impartial tribunal. ${ }^{222}$ Disqualification law should be directed to the mamtenance of this impartiality.

The elimination of all bias is the ideal, but the actual existence of bias can almost never be proven. ${ }^{223}$ This difficulty has led many commentators to call for disqualification when the judge appears to be biased, whether or not she actually is. ${ }^{224}$ The United States Supreine Court has blessed this approach, ${ }^{225}$ but the California Supreme Court recently rejected the appearance of bias test as vague and unmanage$a^{2}$ ble $^{226}$ and held that administrative law officers must actually be biased to be disqualified. ${ }^{227}$

A nore useful view is that there is only one reason for disqualification: that a party reasonably beheves the judge may be partial. 228

218. Frank, Disqualification of Judges, supra note 7, at 610 n.15.

219. See note 7 and accompanying text supra.

220. For application of this point, see the discussion of Clyma v. Kennedy, 64 Conn. 310, 29 A. 539 (1894), in note 13 and accompanying text supra.

221. Frank, Disqualification of Judges, supra note 7, at 619.

222. See note 10 supra.

223. See Solberg v. Superior Court, 19 Cal. 3d at 193 n.10, 561 P.2d at 1155 n.10, 137 Cal. Rptr. at 467 n.10.

224. See, e.g., Note, Disqualification of Judges and Justices in the Federal Courts, 86 HARv. L. REv. 736, 764 (1973); Note, Disqualification of a Federal District Judge for Bias-The Standard Under Section 144, 57 MnN. L. REv. 749, $763-69$ (1973); Comment, Disqualification of Federal Judges: Statutory Right to Recusal and the 1974 Amendments to Title 28, 31 Sw. L.J. 887, 904 (1977); Note, Disqualification of Judges for Bias or Prejudice-A New Approach, 1972 UTAH L. Rev. 448, 450.

225. Sce Peters v. Kiff, 407 U.S. 493, 502 (1972); Commonwealth Coatings Corp. v. Continental Cas. Co., 393 U.S. 145, 150 (1968).

226. Andrews v. Agricultural Labor Relations Bd., 28 Cal. 3d 781, 793, 623 P.2d 151, 157, 171 Cal. Rptr. 590, 596 (1981). Yet, Justice Mosk's argument was undermined by admissions that peremptory challenges, financial interest, personal knowledge, and prior relationships do allow disqualification for merely the appearance of bias. $I d$. at $791 \mathrm{n} .4,793 \mathrm{n} .5,623$ P.2d at $156 \mathrm{n} .4,157$ n.5, 171 Cal. Rptr. at 590 n.4, 591 n.5.

227. Id. at 781,623 P.2d at $159,171 \mathrm{Cal}$. Rptr. at 598 .

228. Section 455 (a) of the federal test cones nearest to codifying this standard by requiring disqualification whenever a judge's impartiality might reasonably be questioned. But $\S 455(\mathrm{~b})$ goes on to say, "He shall also disqualify himself in the following circumstances . . . " (emphasis added). The use of the word "also" indicates that the elements in $\$ 455(\mathrm{~b})$ are distinct from 
Under this view, personal knowledge, prior relationship, and financial interest are not independent reasons justifying disqualification, but merely indications of potential partiality. This test focuses on the reasonableness of the litigant's belief in the existence of bias, which is more concrete than a nebulous notion of how biased a judge appears to society. Although the test may be difficult to apply, courts certainly have more experience at passing on the reasonableness of a party's conduct and behefs than they do at determining apparent prejudice. This test also avoids the practical problems of proving actual bias and is, thus, superior to both the actual bias and the appearance of bias approaches.

In focusing on the reasonable belief of bias, disqualification law has a unified, consistent perspective. Rather than asking whether the financial interest is that of a ratepayer or a shareholder, ${ }^{229}$ the issue is whether it is reasonable or unreasonable to believe that the financial stake would affect the judge's judgment. ${ }^{230}$ Rigid and mconsistent rules are rejected in favor of a more flexible approach that will yield consistent results by focusing on the proper goal of disqualification law.

\section{B. Integrating Goals with Substance and Procedure}

If disqualification law is redefined to einphasize reasonable beliefs rather than a checklist of sins, the issue of how to implement this goal remaims. The approach suggested here involves the use of different procedural methods in colmection with different substantive allegations. $^{231}$

Before examining the interplay between substance and procedure, it is necessary to poimt out that two types of allegations of fact may

$\S 455$ (a). The statute attempts to separate the subjective notion of impartiality from the objective situations listed in $\S 455(\mathrm{~b})$. The view argued for here suggests this dichotouny is misleading. A better approach, like that of the ABA Canons, is to identify the situations in $\S 455(\mathrm{~b})$ as objective indicia of partiality. See ABA CODE OF Judicial CONDUCT, Canon 3C(1). The separation into $\S 455(\mathrm{a})$ and $\S 455(\mathrm{~b})$ may have been done only to distinguisl clearly between acceptable and unacceptable situations of waiver. See 28 U.S.C. 455(e) (Supp. III 1979); Senate Hearings on $S$. 1064, supra note 1, at 75 . The cliange was opposed by Senator Bayl at the final learings on amended $\S 455$. Id. at 76 .

229. See notes 47-55 and accompanying text supra.

230. In other cases, the issue would be the reasonableness of the belief of prejudice rather than whether the judge's relative is a partner or an associate in the firm arguing the case, see notes 27-31 and accompanying text supra, or whether the judge's suspect relationslip is with a relative or a close friend, see note 38 supra. See generally Part I, Section A of this Comment.

231. The same standards and procedures should apply to both trial and appellate judges. The systems are marred by inexplicable distimctions. For example, peremptory challenges in California apply to trial judges but not appellate judges. On the federal level, affidavits of prejudice under $\S 144$ apply only to trial judges, but the section has frequently been given a broader apphication. See notes 5, 100 \& 101 supra. A unified standard would focus on the reasonable belief in partiality at any judicial level. 
support a motion for disqualification. First, there are descriptive facts relating to certain activities or relations of the judge, such as ownership of stock in $X$ Co., having been an attorney with $Y$ ten years ago, or being the brother of $Z$. An entirely distinct factual allegation is one that relates to the mental processes of the judge, such as the allegation in Berger that the judge did not like German-Americans. Note that only the second type of factual allegation has an attitudinal coinponent.

Nonattitudinal allegations are easier to verify than are attitudinal allegations, because their source may be found in docuinents such as employinent contracts, financial records and birth certificates, while the source of attitudes is the mind of the challenged judge. Proof of attitudes will depend largely upon the fortuitous occurrence of the judge stating or recording his prejudice. ${ }^{232}$ This critical distimction suggests that it may be proper to require different procedures for assessing the different types of allegations.

\section{Nonattitudinal Facts and the Sufficiency of Facts Test}

The existence of certain nonattitudinal facts should be sufficient to support a reasonable behef on the part of a litigant that the judge will be partial. Such situations are described generally by the classes of substantive reasons discussed in Part I under the headings of personal knowledge, prior relationships, and financial interest. When sufficient facts exist and the judge has not disqualified herself, parties or attorneys should be permitted to raise the issues by affidavit.

The evaluation of nonattitudinal facts would best be handled under a inodified sufficiency of facts test, ${ }^{233}$ that is, if the facts alleged are sufficient to support a reasonable belief im partiality, disqualification should ensue. The sufficiency of facts standard is preferable because nonattitudinal facts are not as likely to be contested and are susceptible to proof by affidavit. Who is to pass upon the sufficiency of the affidavit is an important related question. The judge challenged is not a wise choice, both because she is an interested party and because she may tend to pass on the truth of the affidavit rather than the sufficiency of it. ${ }^{234} \mathrm{~A}$ better procedure would be to file the affidavit with the presiding judge of the court, ${ }^{235}$ with a copy to the challenged judge.

This procedure would permit the challenged judge either to withdraw upon filing of the affidavit or await the determination by the pre-

232. See notes 71-74 and accompanying text supra.

233. The sufficiency of facts test is discussed at notes 124-25 and accompanying text supra.

234. This tendency is illustrated by Judge Sirica's remarks in United States v. Hanrahan, 248 F. Supp. 471 (D.D.C. 1965), affd sab nom. Tynan v. United States, 376 F.2d 761 (D.C. Cir.), cert. denied, 389 U.S. 845 (1967), discussed in notes 128-31 supra.

235. When the allegations are directed at the presiding judge, the affidavit should be filed with the head of the appellate court overseeing the court mvolved. This will avoid allowing a 
siding judge. The latter judge must review the affidavit to deterinine whether the nonattitudinal facts alleged appear to be true and support a reasonable belief that the challenged judge would be partial. This means that a behief based on the de minimis ownership of stock may be rejected as unreasonable, ${ }^{236}$ as may a belief based on a minor interest as a ratepayer ${ }^{237}$ or long-past associations with counsel. ${ }^{238}$ Flexibility is therefore permitted in assessing the alleged partiality of a judge, but the decision would never be made by the challenged judge herself.

\section{Attitudinal Facts and the Mini-Hearing Review}

A different situation is involved when the party does not rely upon the existence of facts as indicia of bias, but rather on opinions of the judge. Because such facts are not readily verifiable, strict procedures should be required to determine the reasonableness of the belief. ${ }^{239}$ As opposed to the modified sufficiency of facts test suggested above, a better procedure here would be a mini-hearing review. Affidavits would still be filed with the presiding judge and challenged judge, but the latter should be given the option of responding to the allegations by filing her own affidavits with the court. This will help reduce the frustration that accompanies the gagging of a challenged judge ${ }^{240}$ and will also help to assure that disqualification will not be based on misleading charges by the party, but only on reasonable beliefs in partiality grounded upon facts. The mini-hearing need not be an excessive use of judicial resources if the presiding judge decides solely on the basis of reviewing the affidavits, without taking testimony froin witnesses. ${ }^{241}$

\section{CONCLUSION}

Disqualification is a sensitive and difficult issue because it involves questions that are personal to a judge. However, the difficulty of these issues does not justify abandoning all standards, which is the approach

judge to pass on her own fitness to sit in a case. See United States v. Grinnell Corp., 384 U.S. 563, 582 n.13 (1966).

Delay may be guarded against by requiring any affidavit filed after the start of the proceeding to bear a heavy burden of establishing good cause why it was not filed previously.

236. See notes $48-49$ and accompanying text supra.

237. See notes $52-55$ and accompanying text supra.

238. See notes 38-39 and accompanying text supra.

239. For example, that the judge has expressed personal contempt for the party is a reasonable belief in her partiality, see note 63 supra; that the judge is black and so is one party is not, see notes $89-91$ and accoinpanying text supra.

240. See notes 177-81 and accompanying text supra.

241. This is the practice followed under California's challenge for cause statute. Formal hearings on the unotion filed under $\S 170(5)$ are not necessary; the judge may decide the inatter with reference only to written declarations. See People v. Powell, 40 Cal. App. 3d 107, 144, 115 Cal. Rptr. 109, 133 (2d Dist.), cert. denied, 420 U.S. 994 (1974). 
of the peremptory challenge. A better approach to disqualification involves a balancing of the practical abilities and limitations of a judge with a litigant's reasonable belief in her partiality. This requires a rethinking of the field, dropping the checklist approach in favor of one that recognizes the distinction between attitudinal and nonattitudinal facts. So viewed, it becomes clear tliat personal knowledge, prior relationships and financial interest are merely indicia of personal bias. This distinction could be better applied by allowing the procedures for resolution of the issue to vary with the substantive allegations of bias.

As long as we rely on human beings rather than automatons to resolve judicial disputes, ${ }^{242}$ absolute impartiality will be only an ideal. We can and should deinand withdrawal by a judge when a litigant has a reasonable belief in her partiality, but this does not inean that litigants should be entitled to the judge of their choice. ${ }^{243}$ While the present system is far from satisfactory, pereinptory challenge proposals are not the answer to difficult questions of disqualification. What is in order is a realistic reexamination of the goals of disqualification law and a inore effective combination of substantive standards with procedural methods to meet those goals.

Edward G. Burg*

242. Andrews v. Agricultural Labor Relations Bd., 28 Cal. 3d at 79l, 623 P.2d at 157, $171 \mathrm{Cal}$. Rptr. at 595.

243. H.R. ReP. No. 93-1453, 93d Cong., 2d Sess. 5, reprinted in [1974] U.S. CODE CONG. \& AD. NEwS 6351, 6355.

* B.A. 1979, University of California, Irvine; third-year student, Boalt Hall School of Law, University of California, Berkeley. 